\title{
SUSTAINABILITY, DISTRIBUTION, AND THE MACROECONOMIC ANALYSIS OF LAW
}

\author{
DOUglas A. KYSAR*
}

\begin{abstract}
Legal economic analysis has traditionally focused on the application of microeconomic theory to questions of legal import. Scholars have genierally regarded macroeconomic effects of legal rules as lying beyond the purview of the legal decisionmaker's jurisdiction. This Article argues that such exclusion of macroeconomic subject matter from legal analysis may rest on a scientifically erroneous view of the economic process. The conventional understanding of the economic process presumes an uilimited supply of material inputs and an infinite natural capacity to absorb waste outputs. Fundamental scientific principles suggest that this understanding is flawed. The economic process must necessarily be limited in scale by the capacity of the ecological superstructure to sustain it. Thus, in addition to the efficient allocation of resources, legal economic analysis also should be concerned with the sustainable maintenance of scale. Consideration of scale effects by legal decisionmakers cannot be safely ignored in the way that distributive effects have been, given that no political mechanism analogous to the tax and transfer system exists to regulate the scale of the macroeconomy.
\end{abstract}

\section{INTRODUCTION}

"[T] he true rationalisn must always transcend itself by recurrence to the concrete in search of inspiration. A self-satisfied rationalism is in effect a form of anti-rationalism. It means an arbitrary halt at a particular set of abstractions." 1

* Assistant Professor of Law, Cornell University. B.A., 1995, Indiana University. J.D., 1998, Harvard University. For lielpful comments on earlier drafts, I thank Robert Bone, Ronald Cass, Herman Daly, Kenneth Dau-Schmidt, Michael Harper, Jon Hanson, Lisa Heinzerling, Keith Hylton, Jannes Salzman, Theodore Sims, and attendees at the Environmental Law Workshop at the Georgetown, University Law Center and the Feminisın, Corporations, and Capitalism Workshop at the Baldy Center for Law and Social Policy of SUNY-Buffalo. I especially thank Jeffrey Rachlinski and Stewart Schwab for their generosity in providing extensive comments and discussing at length the issues addressed herein. All misjudgments, errors, and omissions are my own.

1 Alfred Norti Whitehead, Science and TIIE Modern World 288-89 (1925). 
In January of 1999, geologist Peter Barrett from Victoria University in Wellington, New Zealand, made a startling announcement at a gathering of international climate experts considering the effects of greenhouse emissions on global warming. ${ }^{2}$ According to Barrett, the West Antarctic ice-sheet, which is approximately the size of Mexico and is currently grounded below sea level, was showing signs of becoming unstable and potentially breaking away. ${ }^{3}$ Scientists have suspected since at least the mid-1990s that Antarctic ice-shelves, which float on the ocean surface and are attached to the grounded icesheets, are retreating at rapid rates. ${ }^{4}$ In early 1999 , researchers at the University of Colorado at Boulder's National Snow and Ice Data Center and the British Antarctic Survey confirmed this hypothesis by using satellite photos to identify a loss of nearly 3000 square kilometers from protective ice shelves around the Antarctic Peninsula in the last year alone. ${ }^{5}$ Compared to the total loss of only 7000 square kilometers in the previous fifty years, these latest fractures suggested that the 4.5 degree increase in mean temperature in Antarctica since the 1940s has had an escalating effect on glacial instability. ${ }^{6}$

What Barrett found more troubling, however, is the relationship between the "full retreat" of the ice-shelves and the crumbling of the West Antarctic ice-sheet. Melting ice-shelves have little net effect on sea levels because the shelves float on the ocean surface, displacing approximately the amount of water they contain. ${ }^{8}$ Ice-sheets, on the other hand, threaten to substantially increase global sea levels if they melt-a prospect rendered more likely by the steady disappearance of surrounding ice-shelves. ${ }^{9}$ Scientists estimate that complete melting of the West Antarctic ice-sheet could result in a six-meter rise in sea levels. ${ }^{10} \mathrm{~A}$ rise of just one meter would affect $3 \%$ of the total land area of the planet, including such major cities as New York, London, and Bangkok, and as much as $30 \%$. of the world's cropland.11

2 See Grover Foley, The Threat of Rising Seas, 29 Ecolocis'r 76, 76 (1999).

${ }^{3}$ See id.

4 See id.

${ }^{5}$ See Jim Kirksey, Warming Puts Antartic Ice Shelves in Full Retreat, Denver PosT, Apr. 10, 1999, at A27.

6 See id.

7 Id.

${ }^{8}$ See Foley, supra note 2, at 77

${ }^{9}$ See id.

${ }^{10}$ See id.

11 See id. 
Of course, there is much uncertainty over this prognosis and, indeed, some debate over whether the observed phenomena are significantly correlated with greenhouse emissions. Nevertheless, the hypothetical disintegration of the West Antarctic ice-sheet reveals many ways in which current global market mechanisms struggle to respond to ecological crises. Assuming that the next century will see the unhinging of the West Antarctic ice-sheet amidst unprecedented climate change, how would the market react? Because no private entity "owns" Antarctica, no property rights-holder has a financial incentive to prevent its steady disappearance. Nor would privatization of Antarctica alleviate this dilemma given that the instrumental value of the frozen land mass (climate stabilization) accrues to all of humanity, not simply its "owner."12 Or, put another way, because the two billion people who live within one hundred kilometers of a vulnerable coastline ${ }^{13}$ face nearly insurmountable problems of coordination and imperfect information, collective market action to reverse global warming trends is unlikely. Indeed, because the people likely to face the most severe consequences of greenhouse emissions have yet to be born, few market actors currently exist to object out of that most powerful economic force: self-interest.

Political action is also hindered by the current market ethos. Because present beneficiaries of the market's failure to internalize the costs of global warming will invest their rents in opposition to any efforts to force internalization, proponents of such market-corrective changes face a daunting political battle. Also, because attempts to price the environmental costs of global atmospheric change are scientifically complex and ethically controversial, market-corrective policies, even when enacted, are imperfect economic instruments. Finally, given that the global warming problem raises issues of international distributive equity that cannot be resolved by an increase in global economic activity (which, at least under current industrial practices, would exacerbate the global warming problem), developed nations accustomed to economic growth as a response to all questions of eq-

12 "Free market environmentalists" advocate the creation and clarification of property rights as a means of overcoming a variety of environmental problems. See, e.g., Terry $\mathrm{L}$. Auderson \& Donald R. Leal, Fre Market Envirommentalism: Lindsight and Foresight, 8 CokNELL.J.L. \& PUis. Por'Y 111, 112 (1998). However, they do not iypically advocate such solutions with respect to envirommental goods and services that camnot be narrowly defined or easily withheld from free-riclers. See id. at 128-30.

is Anne Platt McGinn, Charting a Neu Coutse for Oceans, in S'A'te of Jus Wort. 78, 78 (Lester R. Brown et al, eds., 1999). 
uity must undergo nothing short of a political and cultural transformation-a prospect rendered dim by the continued refusal of the United States to adopt the Kyoto Protocol.14

For these and other reasons, conventional economic policy struggles to respond to ecological crises such as the problem of global warming. This Article attempts to locate the cause of that struggle in the conceptual underpinnings of macroeconomic theory. Put simply, standard macroeconomics utilizes assumptions about the relationship between human and ecological activity that may well lack a sound scientific basis. Moreover, once alternative assumptions are put into place, the course of macroeconomic theory shifts in ways that carry dramatic implications for legal economic analysis. Most notably, the revised theory raises questions about the justification generally given for excluding macroeconomic subject matter from the study of law and economics.

Since its inception, law and economics has attracted criticism from scholars who find its assumptions unrealistic. ${ }^{15}$ For a long time, this response was purely critical in form, exposing as flawed the behavioral assumptions of law and economics without proposing corresponding changes to increase its veracity. In recent years, however, a group of scholars has devoted considerable insight and energy to the project of behavioral law and economics. ${ }^{16}$ This emerging subdisci-

14 The Kyoto Protocol is an agreement reached by member nations of the United Nations Framework Comvention on Climate Clıange to reduce global emissions of carbon dioxide and other greenhouse gases. See lhird Conference of the Parties (COP-3) to the United Nations Frannework Convention on Clinate Change, Dec. 11, 1997, 37 I.L.M. 22. Allough P'tesident Clinton signed the theaty in 1997, the United States Sente failed to ratify it and the Bush Admitistration later refuted U.S. agreenent with the treaty's principles.

${ }^{15}$ See, e.g., Mark Kelman, Choice and Utility, 1979 Wis. L. Rev. 769 (1979); Mark Kelman, Constumption Theory, Production Theory, and Ideology in the Coase Theorem, 52 S. CAL. L. Rkv. 669 (1979); Duncan Kemuedy, Cost-Benefit Analysis of Entitlement Problems: A Critique, 33 STAN. L. Rev. 387 (1981); Arthur Allen Leff, Economic Analysis of Law: Some Realism About Nominalism, 60 VA. L. Rev. 451 (1974); Riclard H. Pildes \& Elizabeth S. Auterson, Slinging Arrous at Democracy: Social Choice Theory, Value Pluralism, and Democratic Politics, 90 Couvm. L. REv. 2121 (1990); Donald H. Regan, The Problem of Social Cost Rerisited, 15 J.L. \& Econ. 427 (1972).

${ }^{16}$ See, e.g., Jon D. Hanson \& Douglas A. Kysar, Taking Behavioralism Seriously: The Problem of Market Manipulation, 74 N.Y.U. L. REv. 630, 633-35 (1999) (describing efforts to incorporate cognitive psychological and other evidence of human behavior into law and economics); Chuistine Jolls, Cass R. Sumstein, \& Richard Thaler, A Behavioral Approach to Law and Economics, 50 Sran. L. Rev. 1471 (1998); Russell B. Korobkin \& Thomas S. Ulen, Law and Behavioral Science: Removing the Rationality Assumption From Law and Economics, 88 Cal. L. Rev. 1051 (2000); Jeffrey J. Raclilinski, The "New" Law and Psychology: A Reply to Critics, skeptics, and Cautious Supporters, 85 CoRnk1.L. L. REv. 739 (2000); Cass R. Sutstein, Behav- 
pline fuses traditional neoclassical economic analysis with lessons drawn from cognitive psychology and decision theory research. The result is a law and economics grounded in assumptions that comport better with observed real-world behavior than the stylized rational actor model featured in conventional law and economics. The fruits of this effort are now dominating new research in law journals, such that it is no overstatement to conclude, "The future of economic analysis of law lies in new and better understandings of decision and choice." 17

With a few notable exceptions, ${ }^{18}$ this project to improve the veracity of law and economics assumptions has focused exclusively on the foundational principles of microeconomics. ${ }^{19} \mathrm{~A}$ group of dedicated scholars within economics, biology, and ecology departments have undertaken a parallel project to reform the assumptions of macroeconomics. These scholars-who have banded together under the moniker, ecological economists-adopt the same methodology as legal behavioral economists. They examine the most robust findings from disciplines outside of economics and utilize those findings to steer economic analysis toward what they believe is greater real-world relevance. As behavioralists instill microeconomic analysis with the teachings of cognitive psychology and decision theory, ecological economists bring the findings of ecology, biology, and environmental science to macroeconomics.

ioral Analysis of Lau, 64 U. Cin. L. Rev. 1175 (1997) |hereinafter, Sunstein, Behavional Analysis].

${ }^{17}$ Sunstein, Behavioral Analysis, supra note 16, at 1175.

${ }^{18}$ See David M. Driesen, The Societal Cost of Environmentnil Regulation: Beyond Administrotive Cost-Benefit Analysis, 24 Ecology L.Q. 545, 563-77 (1997) (assessing the merils of costbenefit assessment of regulatory options in light of macrocconomic considerations such as long-term economic stability, employment maximization, and sustainability): Jeff L. Lewin, Toward a New Ecological Law EO Economirs, in Law and Economics: New and CRi'Ticat. Persrucirves 249 (Robin l'aul Malloy \& Christopher K. Braun eds., 1995) (arguing for the incorporation of ecological cconomic concepts into legal analysis).

${ }^{19}$ This narrowness of focus comes with good reason: law and economics itself las been restricted targely to applications of microeconomic theory. As Mark Kelman has noted, "When legal scholars and law students discuss the impact of economics on their unclerstancling of law, they invariably think about microeconomics, not macrocconomics." Mink Kelman, Could Lauyers Stop Recessions? Speculations on Latw and Macroeconomics, 45 STAN. L. Rav. 1215, 1216 (1993) (emphasis omitted). Thomas Ulen, a leating law and economics scholar, has likewise noted that "[1 the novel aspect of law and economics scholarship) is its use of microeconomic theory to examine the consequences of legal ruies and instiutions in the core areas of the common law-property, contracts, torts, civil procedhre, criminal law aul procedure, and constitutional law." Thomas S. Ulen, The Lessons of Law and Economics, 2 J. LEGAL ECON. 103, 105 (1992) (emphasis added). 
This Article introduces the field of ecological economics and analyzes its potential use as a macroeconomics ${ }^{20}$ for legal analysis. Rather than engage in a full critical evaluation of the foundational assumptions of ecological economics, ${ }^{21}$ this Article largely accepts them as true and asks the speculative question, "What would that mean for legal analysis?" As will be seen, the implications could be quite broad. Traditionally, legal economists have given little attention to macroeconomic subject matter: ${ }^{22}$ If the tenets of ecological economics are to be believed, this narrowness of focus may rest on unfounded assumptions about the nature of human economic activity and its relationship to the environment. Indeed, if the ecological economic understanding of this relationship is correct, the impact of legal rules on the macroeconomy could become an issue of central theoretical concern to legal scholars.

Ecological economics offers this potential because it is built around a more complex understanding of human economic goals than traditional economic analysis. Economists recognize two primary functions served by the market: the allocation of resources among competing uses (allocation) and the distribution of wealth anong market participants (distribution). In grossly simplified terms, economists believe that the first function suggests market policies designed to maximize allocative efficiency, while the second function requires a social decision best left to the political process. Ecological economists argue that a third function served by the market has been overlooked by conventional analysis: moderation of the scale of human economic activity vis-à-vis the ecological superstructure upon which all life and activity depends (scale). While allocation determines the purposes for which resources are used, scale determines the rate and amounts of resources that are used.

${ }^{20}$ As will be seen, ecological economists do not devote significant attention to many of the "stindard" macrocconomic subjects that readers may expect to encounter (i.e., inflation, business cycles, deficit spending, and monetary policy). Rather, they focus upon the more basic concerns of econonic growth and total output, believing that fumdanental conceptual errors have been made at that level, before one even addresses the more specific, technical macrocconomic subjects.

21 For reasons explained infra text accompatying notes 256-287, the necessity of adopting an ecological ecomomic worldview depends on highly empirical questions about the ability of human teclunology to circumvent naturally imposed constraints on economic expansion, questions that will only be answered by the annals of history. This Article therefore does not ask the presently manswerable question, "Are the ecological economists right?" Instead, it asks the more fruitful question, "What if they are right?"

r2 See supra note 19. 
Like their orthodox counterparts, ecological economists offer a norm to accompany this concept. Just as economists almost instinctively believe that allocative efficiency should be maximized, ecological economists tend to believe that the scale of the economy should be sustainable, that is, capable of reproduction in perpetuity (or its practical equivalent). Readers who are uncomfortable with some of the more dramatic implications of sustainability should bear in mind that the fundamental insight of ecological economics is a recognition of the concept of scale, not necessarily the norm of sustainability. Whether or not one accepts all of the implications of sustainability as a norm, ecological economists seek acknowledgment that human economic activity impacts the enviromment and that the size and rate of that impact is a legitimate subject of social and legal influence.

Part I of this Article begins with a brief history of ecological economics, tracing its development from a few foundational articles in the late 1960 s and early 1970 s to a lively transdisciplinary subject that forms the intellectual core of today's major international efforts to achieve sustainable development. ${ }^{23}$ The fundamental principles of ecological economics are examined to provide the reader with a primer on this discipline which has been described as "the science and management of sustainability." ${ }^{4}$ Representative applications of ecological economic concepts are reviewed, demonstrating the potential ability of such concepts to influence economic activity to become more consonant with the ecological needs of the earth.

Part II addresses several criticisms that have been raised against ecological economics and argues that most miss their mark. ${ }^{25}$ Often, critics of ecological economics raise attacks that reflect a misunderstanding of its basic concepts. As Part II demonstrates, once these criticisms are taken to their logical conclusions, they turn out to strengthen, rather than undermine the emerging discipline. Nevertheless, one particular criticism-relating to the possibility of market forces to inspire the discovery or creation of substitutes for scarce natural resources-remains a powerful challenge to ecological economics. Economists often view price as a built-in market mechanism for conservation: as resources grow scarce, they rise in price and inspire the development of substitute materials. Such dynamics, on the

29 See infra notes 27-207 and accompanying text.

24 See Ecological Economics: The Science anis Managlamen't of Sustainalility (Robert Costasıa ed., 1991).

25 See infra notes 208-295 and accompanying texı. 
economist's account, obviate the need for direct legal control of market exploitation of natural resources.

Ecological economists oppose this view by arguing, among other things, that widespread externalization of environmental costs undermines the reliability of the price mechanism as a regulator of resource-taxing activity. Moreover, they contend that even a perfectly functioning price system would fail to control the scale of the economy adequately. Many of the most important consequences of scale expansion are properly conceived of as price-determining, not pricedetermined. Decisionmaking about how massive the scale of the economy ought to grow in relation to the environment, therefore, should not occur exclusively through decentralized market microdecisions, no matter how well the price mechanism is functioning.

Part III speculates on the broader implications of ecological economics for legal analysis, assuming that ecological economists are correct in their view of the relationship between human and natural capital. ${ }^{26}$ This Part argues that incorporation of ecological economic insights into legal analysis is desirable both to enhance the use of macroeconomics within legal theory, and to ensure that scholars confront the problem of sustainability when making legal policy recommendations.

\section{An Introduction to Ecological Economics}

The discipline of ecological economics is intimately concerned with the dynamic processes that drive environmental change, especially those processes that involve the intersection of human and ecosystem activity. Moreover; the discipline is also focused, like traditional economics, on market transactions. As such, the discipline is particularly well suited to guide economic and legal policymaking under conditions of increasing ecological strain. To better understand the potential advantages of ecological economics as an analytical framework, this Part begins with a brief review of its history, followed by a primer on fundamental ecological economic concepts.

\section{A. A Brief History}

Although many ecological economic themes resonate with century old thoughts of the classic economist John Stuart Mill, ${ }^{27}$ the dis-

26. See infra notes 296-318 and accompanying text.

${ }^{27}$ Indeed, Mill's prescient thoughts are worth quoting at the ontset: 
cipline's modern origins can be traced to three landmark articles from the late 1960s and early 1970s.

\section{1. "The Economics of the Coming Spaceship Earth"}

The first of the three landmark articles came in 1966 from past president of the American Economic Association, Kemneth Boulding. Entitled The Economics of the Coming Spaceship Earth, Boulding's essay was a metaphorical masterpiece. ${ }^{28}$ His thesis was simple: while mainstream economists view the economy as an open system of pure exchange value with externalized environmental consequences, the steady progression of humanity toward the carrying capacity of the earth will require that economic activity be reconceived as a closed system within which environmental consequences must be considered. Of course, economists since Arthur Pigou have recognized the existence of "externalities" such as the cost of pollution from industrial activity. ${ }^{29}$ Yet Boulding's essay revealed something deeper than Pigou's mere microeconomic failure of private cost functions to reflect full social costs. The vivid and enduring language that Boulding used to explore the contrast between open and closed visions of the economic system revealed a macroeconomic problem-an economic culture predisposed to the creation of Pigouvian externalities on a massive, public scale.

Boulding summarized the mainstream economic perspective as the "cowboy economy," in which natural frontiers are seen as limitless, resources as inexhaustible, and wastes as innocuous. ${ }^{30}$ Such a perspective fosters the "reckless, exploitative, romantic, and violent behavior"

If the earth must lose that great portion of its pleasantmess which it owes to things that the unlimited increase of weath and population would extirpate from it, for the mere purpose of enabling it to support a larger, but not a better or a happier population, I sincerely hope, for the sake of posterity, that they will be content to be stationary, long before necessity compels them to it.

Join Stuari Mill, Principless of Political Economy 750-51 (Augustus M. Kelley ed., 1987). The current delate between mainstream and ecological cconomists can be understood as a clebate over whelher Mill's stationary state has become, as he predicted, necessary, rather than merely desirable.

${ }^{28}$ Kenneth E. Buulding, The Economics of the Coming Spaceship Earth, reprinted in VAluING. THE EARTH: Economics, Ecology, ETHucs 297 (lemman E. Daly \& Kenneth N. 'Jownscud eds., 1993).

29 See A.C. P'icou, Tue Economics of Wet.fare 149-79 (1920) (introducing and discussing the concept of market externalities).

${ }^{30}$ Boulding, supra note 28 , at 303. 
to be expected of a cowboy. ${ }^{31}$ Relative to the economist's task, "[i]f there are infinite reservoirs from which material can be obtained and into which effluvia can be deposited, then the throughput [that is, the sheer volume of production and consumption in an economy] is at least a plausible measure of the success of the economy." 32 In other words, if there are no environmental or social repercussions to economic growth, then an increase in the gross national product (GNP) would seem to represent an uncontroversial macroeconomic goal. Indeed, Boulding argued that the preanalytic view of the economy as an open system unconstrained by environmental factors leads to an economics fixated with growth. ${ }^{39}$

In contrast to this "cowboy economy," Boulding championed a view of the "spaceman economy," in which the earth is a closed system necessitating consideration and careful plamning of the consequences of human economic activity. ${ }^{34}$ In a spaceship, one cannot ignore the byproducts of production and consumption. ${ }^{35}$ Likewise on the "Spaceship Earth," humans must be concerned with the capacity of the global vehicle to support their needs and accommodate their wastes. ${ }^{36}$ Therefore, "in the spaceman economy, throughput is by no means a desideratum, and is indeed to be regarded as something to be minimized rather than maximized. ${ }^{97}$ Humans must be concerned with the quality of economic activity that occurs, particularly as it relates to the creation of enduring, efficient, and useful capital stocks. Like Mill, ${ }^{38}$ Boulding saw the shift of emphasis from the quantitative

$31 \mathrm{Id}$.

32 Ill.

s3 See id. at 303-04.

34 Id. at 303 .

35 Crew members aboat the Mir space station experienced a real-life example of Boulding's metaphorical warniing: "Somewhere up there in the starry void, two Russian cosmonauts and an American astronaut have been facing a problem Moscow's mission control has been tuable to solve: 'Their toilet tanks are overflowing." Uli Sclumezer; Even Orbiting Cosmonauts Occasionally Need a Plumber; Wir Toilet Tanks Full and No Helper at Hand, Wasn. Post, Nov. 12, 1996, at A12.

${ }^{36}$ Bontding, supra note 28 , at 297.

${ }^{37}$ Id. at 304 .

38 Mill wrote:

[A] stationary condition of capital and population implies no stationary state of luman inprovement. 'There would be as much scope as ever for all kinds of mental culture, and moral and social progress; as much room for inproving the Art of living, and more likelihood of its being improved, when mints ceased to be engrossed by the art of getting on. Even the industrial arts might be as earnestly and as successfully cultivated, with this sole clifference, that in- 
magnitude of income flows to the quality of capital stock as not just an environmental necessity, but an improvement in social welfare: "The essential measure of the success of the economy is not production and consumption at all, but the nature, extent, quality, and complexity of the total capital stock, including in this the state of the human bodies and minds included in the system." 39

Boulding concluded his essay by puzzling over why his views placed him in such a narrow minority of contemporary thinkers. There is, he suspected, a widely shared feeling that "the spaceman economy is still a good way off (at least beyond the lifetimes of any now living), so let us eat, drink, spend, extract and pollute, and be as merry as we can, and let posterity worry about the spaceship earth." 40 What troubled Boulding most about this perspective, besides its ethical myopia, was that he believed " $[t]$ he shadow of the future spaceship ... is already falling over our spendthrift merriment." 41 Over three decades later, the shadow would seem to have darkened and spread, yet mainstream economics is no more receptive to his ideas. As Boulding wryly noted in a reflection on his earlier article, "It seems to be very hard to organize a long-run crisis. "42

\section{2. "The Tragedy of the Commons"}

While Boulding's visionary essay contained the intellectual seeds from which ecological economics would spring, biologist Garrett Hardin's famous 1968 article, The Tragedy of the Commons, might be considered the cultural beginning of ecological economics. ${ }^{43}$ Though its themes were well-explored over a decade earlier by an economist, ${ }^{44}$ Hardin's eloquent article had a far-ranging impact precisely because his approach was not restricted to an economic inquiry. The fusion of Hardin's biological insights with his elementary economic analysis produced a work of near-universal resonance. It is this brand of trans-

stead of serving no purpose but the increase of weali1, inclustrial improvements would produce their legitimate effect, that of abristging labous.

MiLe, supra note 27, a1 75!.

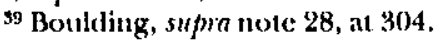

40 Jd. al 305 .

${ }^{41} \mathrm{Id}$. at 307.

${ }^{42}$ Kenneth E. Boulding, Spaceship Earth Revisited, in Valunng 'Tm: EArTit: Economics, Ecologr, Erucs 311, 311 (Ierman E. Daly \& Kenneth N. Townsend eds., 1993).

${ }^{43}$ Garrett Hardin, The Tragedy of the Commons, $162 \mathrm{Scr}, 1243$ (1968).

${ }^{44}$ See H. Scull Gordon, The Economic Theory of a Common-l'moperty Resources: The Fishery, 62 J. PoL. Econ, 124 (1954). 
disciplinary thinking that has uniquely characterized ecological economics in the decades following The Tragedy of the Commons.

Hardin's piece focused on the well-known problem posed by allowing open access to public resources. ${ }^{45} \mathrm{He}$ described this problem by evoking simple agrarian imagery, much like that other 1960 s economics masterpiece, The Problem of Social Cost: ${ }^{46}$

The tragedy of the commons develops in this way. Picture a pasture open to all. It is to be expected that each herdsman will try to keep as many cattle as possible on the commons .... [Because the positive effects of an additional animal accrue to the individual while the negative effects are spread across all commons users], the rational herdsman concludes that the only sensible course for him to pursue is to add another animal to the herd. And another; and another .... But this is the conclusion reached by each and every rational herdsman sharing a commons. Therein is the tragedy. Each man is locked into a system that compels him to increase his herd without limit-in a world that is limited. Ruin is the destination toward which all men rush, each pursing his own best interest in a society that believes in the freedom of the commons. Freedom in a commons brings ruin to all. ${ }^{47}$

This tragedy was, of course, long known to economists under such names as the problem of "common pool resources." 48 For many economists, however, the problem was a mere curiosity, a quirky be-

45 There has been some confision over terminology. As David Pearce has noted, the term "commons" traditionally referred to commonly owned property that had certain social norms constraining its use. Thus, the "tragedy of the commons" did not, strictly speaking, happen to the commons. Rather the problem occurs with respect to "openaccess" property, in which no constraints, legal or social, prevent overutilization of the resource. See R. Kerky Turner et al., Environmental Economics: An El.ementary INTRODUCrion 210 (1993). The elegance of Hardin's phrasing, however, weiglis in fivor of its use, respite the ambiguity.

${ }^{16}$ Ronald H. Coase, The Problem of Social Cost, $3 \mathrm{~J}$. LAw \& Econ. 1 (1960). In the category of articles with agratian imagery, one might also mention the instant classic by Robert Ellickson. His expluration of the use of norms annong neighbors to resolve clisputes provides a vivid illustration of how the "commons" might be regulated by social, tather than legal, restraints. See Ronek't C. Ellickson, Order Without law: How Netghbors SteTTHE Disputes (1991).

${ }^{7}$ Hatclin, supra note 43 , at 1244.

${ }^{18}$ See Ganrett Hardin, Second Thoughts on "The Thagedy of the Commons," in Valuung TIIE Earth: Economics, Ecology, EThics 146, 146 (Herman E. Daly \& Kenneth N. 'Townsend eds., 1993). 
havioral exception to the general rule of allocative market efficiency. ${ }^{49}$ For Hardin, on the other hand, the tragedy of the commons was pervasive, explaining a wealth of urgent contemporary problems, from the extinction of marine life $\mathrm{e}^{50}$ to the pollution of air and water ${ }^{51}$ to the rapid growth of human population. 52

To circumvent the tragedy, Hardin recommended drastic legislative action, which he evocatively called "mutual coercion, mutually agreed upon by the majority of the people affected. ${ }^{m 3}$ Like Mill and Boulding, ${ }^{54}$ Hardin viewed his reconmendation as offering an affirmative improvement in social welfare in addition to its environmental benefits: "Individuals locked into a logic of the commons are free only to bring on universal ruin; once they see the necessity of mutual coercion, they become free to pursue other goals. "55

As a foundational article in the development of ecological economics, The Tragedy of the Commons served to remind economists that their discipline did not exist in a vacuum. The article's implicit message, as Hardin would later reflect, was that economists could only continue their self-imposed disciplinary isolation at the cost of ecological health and, perhaps, human survival: "Before significant political change can be instituted, there must be a fundamental improvement in the theory and practice of economics, which needs to be firmly tied down to the sort of conservation laws that have proven essential to the progress of the natural sciences." 56 Ecological economics can be seen as the collaborative effort of a wide range of thinkers to respond to Hardin's challenge.

\section{3. "The Entropy Law and the Economic Problem"}

The third ecological economics pillar came in the form of a lecture by Vanderbilt economist Nicholas Georgescu-Roegen entitled The

${ }^{9}$ See David R. IIolas, The Role of Law in Defining Sustainable Druelopment: NEPA Reconsidered, 3 Widener L. SYMP. J. 1, 25-26 (1998) ("Curlent law mirrors the view of most economists that environmental externalities are an inconvenicn theoretical contaminant in an otherwise elegant market system. Externalitics are only an afterthought in a legal system driven by an individual/market oriented paradigm,").

${ }^{50}$ See 1 tardin, supra note 43 , at 1245.

${ }^{31}$ See id.

${ }^{32}$ See id. at 1246.

ss $I d$. at 1247.

${ }^{54}$ See supra text accompanying notes 38-39.

${ }^{55}$ Hardin, stupra note 43 , at 1248 .

${ }^{56}$ Hardin, stipra note 48, at 149. 
Entropy Law and the Economic Problem. ${ }^{57}$ The lecture's themes were explored first in an earlier work which caused famed economist Paul Samuelson to note, "I defy any informed economist to remain complacent after meditating over this essay. "58 What Georgescu-Roegen attempted to accomplish was nothing short of a scientific refutation of macroeconomic theory. Invoking the laws of thermodynamics, Georgescu-Roegen argued that "matter-energy [necessarily] enters the economic process in a state of low entropy and comes out of it in a state of high entropy," where entropy refers to the degree of chaos or disorder present in an energy source. ${ }^{59}$ Fossil fuels represent the product of millions of years of condensed solar energy - as such, they are potent sources of available energy (a low-entropy energy source). Once burned, the fossil fuels become a mixture of gases that dissipate into the atmosphere and become largely worthless, even harmful, to humans (a high-entropy energy source).

For Georgescu-Roegen, the important point was this: the second law of thermodynamics states that matter-energy irrevocably moves from a condition of low- to high-entropy, from ordered, available energy to chaotic, unavailable energy ${ }^{60}$ In other words, "the cost of any biological or economic enterprise is always greater than the product." 61 Thus, although animals do grow in size and species do evolve in complexity, in actuality their physical growth and adaptation exacts a higher cost in terms of pure matter-energy than their new forms represent. More generally, any time that a material subsystem appears to have violated the second law of thermodynamics, one need only look outside the subsystem to find a source of low-entropy that is being driven to chaos. In short, Georgescu-Roegen demonstrated that the common-sense view of resources as limited, expressed earlier by Boulding, has theoretical support in physics: resources are limited because their use necessarily entails their dissipation.

Given this biophysical truth, ${ }^{62}$ Georgescu-Roegen set out to turn standard macroeconomics on its head. Rather than an isolated ex-

\footnotetext{
${ }^{57}$ Nicholas Georgescut-Roegen, The Entropy Law and the Economic Problem, reprinted in Valuing the EarTh: Economics, Ecolocr, Ermics 75 (Hesman E., Daly \& Kenneth N. Townsend eds., 1993).

58 Herman E. Daly, Beyond Growrh: Tie Economics of Sustainable DevelopMENT 192 (1996).

${ }^{59}$ See Georgescu-Roegen, supra note 57 , at 77.

60 See id. at 78, 80 .

${ }^{61} \mathrm{Id}$. at 80.

62 Some have questioned whether the second law of thermodymamics represents a "truth." 'lhis objection is addressed infra text accompanying notes 217-222.
} 
change loop capable of perpetual expansion, the economic process is fixed to a base of materials that is subject to identifiable constraints. "It is because of these constraints that the economic process has a unidirectional irrevocable evolution." 63 All economic activity must necessarily involve a step, however small, toward the exhaustion of available energy. Georgescu-Roegen's conception of entropy laws and economic activity is unforgiving. Nuclear power, materials recycling, and any other technological "solution" to matter-energy scarcity is a delusion: "There is no free recycling just as there is no wasteless energy." ${ }^{4}$ Even if humans were to give up their dependence on pollution-producing fossil fuels in favor of renewable energy sources, they could not escape the laws of entropy. Solar energy, too, tends to chaos in the long-run. ${ }^{65}$

Georgescu-Roegen's conclusion is powerful, if daunting:

The upshot is clear: Every time we produce a Cadillac, we inrevocably destroy an amount of low entropy that could otherwise be used for producing a plow or a spade. In other words, every time we produce a Cadillac, we do it at the cost of decreasing the number of human lives in the future. Economic development through industrial abundance may be a blessing for us now and for those who will be able to enjoy it in the near future, but it is definitely against the interest of the human species as a whole, if its interest is to have a lifespan as long as it is compatible with its dowry of low elltropy. ${ }^{66}$

In order to preserve the species as long as possible, GeorgescuRoegen believed that humans must adopt an ethic of prudent management of fixed terrestrial resources. He would later advocate the use of solar energy sources, stabilization of population sizes, reduction

os Georgescu-Roegen, supra note 57, at 81 .

at Id. at 83.

as Of course, this "long-rum" is estimated to be some five-billion years long, see id. at 83 , and appears all the more likely to include a developed human civilization within its benefice given advances in solar technology mate since the time: of Georgescu-Roegen's lecture. Nevertheless, the massive time frame involved with the sut's clissipation does not change the fact that solar activity is bound by the laws of thetmodymanics. See infin text accompanying notes 217-222. More importantly, there appear to be significant current constraints on the availability of solar energy for human appropriation, given that one camnot advance the rate of solar entropic flow. See infra lext accompanying noles 276-287.

60 Georgescu-Rocgen, supra note 57 , at 85. 
of consumption habits, and other policy measures as part of this prudent management. ${ }^{67}$

It bears noting that Georegescu-Roegen's conclusion that humanity should "have a lifespan as long as it is compatible with its dowry of low entropy" represents a conflation of the concept of scale and the norm of sustainability ${ }^{68}$ As described above, ${ }^{69}$ ecological economics does not require one to accept the goal of lengthening the survival of the species at any cost; rather, it requires one to acknowledge that some decision about intergenerational resource distribution must be made. From the perspective of ecological economics, Georgescu-Roegen's main accomplishment was in throwing down a theoretical gauntlet to which mainstream economics has yet to respond. The failure to refute or even address the logic of Georgescu-Roegen's argument created a void in standard economic analysis that ecological economics has sought to fill.

\section{The Emergence of Ecological Economics}

In 1973, Herman Daly published a collection of essays, including the three just discussed, that marked the formal arrival of ecological economics as a field of study. ${ }^{70}$ The subject could only be described as transdisciplinary, utilizing concepts from a variety of fields including economics, ecology, biology, and physics, yet grounded in a set of foundational principles unique to it. Following this genesis, ecological economics gained steady acceptance until "[i]t now boasts several research institutes around the world, as well as the 1500 -member International Society for Ecological Economics."71 Since the Brundtland Commission focused the world's attention on the concept of sustainability in $1987,{ }^{72}$ ecological economics has only grown in prominence: no discipline has been more concerned with defining a sustainable level of human activity within the natural ecosystem than

${ }^{67}$ See Nicholas Georgescu-Roegen, Energy and Economic Myths, in Valuing THE EarTh: Economics, Ecology, EThics 89, 103-05 (Hetman E. Daly \& Kenmeth N. Townsend eds., 1993).

68 Georgescu-Roegen, supra note 57 , at 85.

${ }^{69}$ See supra text accompanying note 22.

70 See Toward a Steady-State Economy (Herman E. Daly ecl., 1973). 35.

71 Jeff Gersh, Bigger, Badder-But Not Better, Tiue Amicus Journal, Jan. 1, 1999, at 32,

72 See Susan L. Smith, Ecologically Sustainable Detelopment: Integrating Economics, Ecology, and Law, 31 WH.LAMETTE L. REv. 261, 272-73 (1995) ("The Brundland Report catapulted the principle of sustainable development to paramount international significance."). 
ecological economics. As a result, international leaders are increasingly turning to its practitioners for guidance.

Throughout this development, most have considered Herman Daly the intellectual figurehead of ecological economics. ${ }^{73}$ For twentyfive years, Daly has been challenging growth economic orthodoxy and championing the discipline of ecological economics. He taught at Louisiana State University for two decades before his views on the mixed value of economic growth attracted the attention of Robert Goodland at the World Bank. ${ }^{74}$ Goodland hired Daly to act as a senior economist at the World Bank for six years, during which Daly vigorously lobbied from within to change the Bank's institutional disregard of the environmental costs of its projects. ${ }^{75}$ After resigning from the World Bank in 1994, Daly assumed his current position at the School of Public Affairs at the University of Maryland. His views achieved international recognition in 1996 when he was awarded, appropriately, the "alternative Nobel Prize."

\section{B. Some Fundamentals}

Although the field is still relatively new and ill-formed, several fundamental concepts have gained sufficient acceptance to be called "standard" ecological economics. This Section examines those concepts in detail.

\section{The Relationship Between Ecological and Economic Systems}

"The vision of modern economics in general, and especially of macroeconomics, is the familiar circular flow diagram. ${ }^{m 7}$ The economy is viewed as a self-contained system within which exchange value circulates between producers and consumers. The macroeconomic loop makes no accounting of the actual resource materials from

${ }^{3}$ See U-Md. Economist Ionored in Netherlands, WASu. Post, Apr: 12, 1996, at B3 (dlescribing Daly as "one of the first economists to focts on environmental problens and ... the founder of the new discipline of ecological economics").

74 See G. Pascal Zachaty, 'Green Economist' Warns Growth May Be Overvatel, Whis. St. J., June 25, 1996, at B1.

${ }^{75}$ Sere id.

${ }^{76}$ See Eronomist at UM Wins 'Alternative Nobel Prize, BAls, Sun, Oct. 3, 1996, at 13A (noting that Daly was awarded an honorary Right Livelihood Awarcl for fostering a discipline "Ihat integiales the key elements of ethics, gutality of life, enviromment and community, in contrast to the mainstream obsession with quantitative econonic growth and fice trade").

77 Herman E. Daly, Elements of Envirommental Macroeronomics, in Ecological LConomics: Tile Scifnce and Management of Sus'minability 32, 33 (Robert Costamza ed., 1991). 
which goods are produced, or the waste matter into which goods are transformed during consumption. Physical dimensions of economic activity simply do not exist in the textbook circular flow diagram. Thus, resource depletion, environmental pollution, impairment of necessary environmental services such as water filtration or carbon absorption, or indeed any other relationship between economic activity and factors outside of the narrow universe of value exchange are ignored by standard macroeconomics. As Daly put it, "It is exactly as if a biology textbook proposed to study an animal only in terms of its circulatory system, without ever mentioning its digestive tract . . ."78

Ecological economists believe that this conception is misguided. Human economic activity impacts the ecological sphere in all phases of production and consumption, in ways both patently obvious, such as the clear-cutting that has occurred in the majority of the forested areas of the globe, ${ }^{79}$ and deceptively subtle, such as the rise of greenhouse gases in the atmosphere from 277 ppmv (parts per million by volume) to 367 ppmv since pre-Industrial times. ${ }^{80}$ Humans are drawing down natural resources at rates that are geologically significant. The Ogallala aquifer; a massive underground source of filtered fresh water which lies beneath several states in the U.S. Great Plains, stood at a relatively constant level for millions of years. In recent decades, however, agricultural irrigation has caused the fossil groundwater to drop at an annual rate of four to six feet, compared to a natural recharge rate of only about one-half inch per year. ${ }^{81}$ The aquifer's shallow southern reaches have already been depleted, causing irrigated land in Texas to shrink by $11 \% .^{82}$

Humans are diverting resources from their ecological paths, causing unforeseen and often harmful consequences. The Colorado River, whose annual water flow is allocated to industrial, agricultural, and municipal uses through a massive system of ten major dams, ${ }^{83}$ has

78 DALX, supra note 58, at 193.

79 See Janet N. Abtamovitz \& Ashley T. Mattoon, Reorienting the Forest Products Economy, in STATE of THE Woksd 60, 60 (Lester R. Brown et al. eds., 1999) (noting that "[b]etween 1980 and 1995 alone, at least 200 million hectares of forest were lost-an area larger than Mexico").

80 Lfster R. Brown, et al., Vital Signs 60 (Linda Starke ed., 1999).

81 See Marc Reisner, Cadillac Deser't: The American Wes't and its Disappearinc. WATER 455 (1986).

82. See Lester R. Brown, Facing Food Srarity, in The Wortowatch Reable on Global. ENvironmental Issues 215, 222 (Lester R. Brown \& Ell Ayres eds., 1998).

8s See Sandra Postel, Where Have All the Rivers Gone?, in The Worldwatch Reader on Global Environmental Issues 173, 178 (Lester R. Brown \& Ed Ayres eds., 1998). 
rarely reached its mouth in the Gulf of California since 1993.84 The resulting salinization of water in the Gulf has decimated shrimp and other fisheries while straining the lives of area fishermen. ${ }^{85}$

Humans are setting in motion complex feedback loops whose little-understood mechanisms could become self-perpetuating. Melting of polar ice caps through global warming could cause the release of billions of tons of methane gas trapped beneath crystal structures on the edges of continental shelves. ${ }^{86}$ One cubic meter of this methane gas has the same ultraviolet radiation trapping effect as twenty cubic neters of carbon dioxide, the most voluminous greenhouse gas produced by human activity. ${ }^{87}$

In light of scientific theory and empirical evidence, therefore, ecological economists argue that the macroeconomic conception of market activity as an isolated system is erroneous. The economy appears to be limited by the constraints of nature. Or, as former Wisconsin governor Gaylord Nelson succinctly put it, "The economy is a wholly-owned subsidiary of the environment." 88

Nevertheless, even international institutions such as the World Bank continue to rely on the rarefied macroeconomic conception of exchange found at the beginning of standard texts. ${ }^{89}$ As Daly notes, "Things are no better when [one] turn [s] to the advanced chapters at the end of most macroeconomic texts, where the topic is growth theory." 90 For years the theory was stated as a simple function involving $\mathrm{K}$ and L, capital and labor. Resource flows and waste output flows were not even a factor in the equation. Thus, the only constraints on economic growth appeared to be the availability of man-made capital and human labor: The limitations of this conception can be demonstrated by a simple example. The United Nations currently estimates that all seventeen of the world's major fisheries are being fished at or beyond capacity, and nine are in serious decline. ${ }^{91}$ In such a situation, the

84 Spe Brown, supra note 82, at 223.

as Sec Postel, supra note 83, at 179-80.

${ }^{86}$ See Peter Bunyard, How Climate Change Could Spiral Out of Control, 29 Ecolocis'r 68, $71(1999)$.

${ }^{87}$ See id.

88 Gerslı, supra note 7 \}, at 34 .

${ }^{89}$ Se DALY, supra note 58, at 5-6 (recounting failed ancmpts to introduce any concept. of the enviromment into a Worlel Bank diagram that pupported to slow, "The Relationshij) Between the Economy and the Environment").

90 Id. at 47.

91 See Peter Weler, It Comes Donth to the Coasts, in THe Worldwatcit Readir on Glonal. Env'ironmin'tal Issues 79, 86 (Lester R. Brown \& Ed Aytes eds., 1998). 
limit to economic growth is not the number of boats or fishermen; rather, the limit is the number of fish.

More recent attempts by economists such as Joseph Stiglitz to introduce resource flows into growth theory ${ }^{92}$ have also been challenged by ecological economists. In these revised equations, "the production function is almost always a multiplicative form . . . in which $\mathrm{R}$ [resource flows] can approach zero with $\mathrm{Y}$ [aggregate production] constant if only we increase $\mathrm{K}$ or $\mathrm{L}$ in a compensatory fashion. ${ }^{\prime 93}$ The idea behind this formulation is that increased use of man-made capital and labor can compensate for reductions in the availability of natural resources or waste assimilative capacity. "Resources are seen as 'necessary' for production, but the anount required can be as little as one likes ... . ${ }^{44}$ Ecological economists believe that this brand of potential growth is also problematic-an increase in the absolute amount of man-made capital or labor generally entails an increase in the depletion of resources or the taxing of assimilative capacity. Such factors are more properly thought of as complements, not substitutes.

As an example of the orthodox view, many economic forecasters view China, with its 1.2 billion people, as an untapped market for goods associated with the affluent Western lifestyle..$^{95}$ In other words, forecasters see the glimmer of economic growth in the development of China. Other commentators, however, argue that if the entire Chinese population were to adopt the lifestyle of consumers in a nation like the United States, the consequent ecological footprint would be catastrophic. ${ }^{96}$ Incleed, it does not appear that the Chinese could even eat like Americans, let alone buy, build, drive, and discard like Americans: "If the current world grain harvest, averaging 1.75 billion tons thus far during the 1990 s, were boosted by roughly 15 percent to 2 billion tons, that harvest-if equitably distributed-could support [only] 2.5 billion people at the American level of consumption. ${ }^{m 7}$ To

92 Joseph E. Stigliz., Grouth with Exhaustible Natural Resources: Efficient and Optimal Growth Paths, 41 Rrv. Econ. STudies 123, 124 (1974).

${ }^{93}$ Dasr, supranote 58, at 48.

${ }^{94} \mathrm{ld}$.

95 . Sie, e.g., JoIn Natsbirt, Mrgatreniss Asta 87 (1996) (repolting that "a billion Chinese want to becone rich and buy millions of 'lVs, washing machines, tefigerators and videocassette recurders"); id. at 92 (arguing that China's recent growth trend will result in a $\$ 7.2$ trillion economy by 2001 , equal in size to the current U.S. economy).

96 See Lesier R. Brown, Who Will Feed China?, in THe Worldwatch ReAder on Global. Environmental. Issues 196 (Lester R. Brown \& Ed Ayres eds., 1998).

${ }^{97}$ Brown, stupra note 82 , at 229 . Thus, China's 1.2 biltion people would consume nearly half of total global grain output, leaving the wortd's remaining 4.5 billion people struggling to oblain even subsistence levels of fool. See id. 
be sure, growth in consumption levels in China will be accompanied by growth in the nation's own productive capacity. It is far from clear, however, that arable land and agricultural productivity can be multiplied in the way that factories can. ${ }^{98}$

\section{The Laws of Thermodynamics}

Assuming that environmental frontiers are not limitless, economics as the science of scarcity therefore must confront the scarcity of natural as well as man-made resources. While mainstream economists believe that they have found a theoretical avenue around this challenge, ${ }^{99}$ ecological economists confront it directly, incorporating the laws of thermodynamics into their analysis in order to better understand the quality of physical exchanges that occur between the ecological system and the economic subsystem. As Georgescu-Roegen demonstrated, such application reveals a disturbing truth about human economic activity (and indeed, about all activity within the material universe). The fixed quantum of matter-energy with which the universe is endowed must necessarily move from a state of highavailability to low-availability, of low-entropy to high-entropy, and of order to chaos. Thus, physical throughput in the human economy must always be conceived of as at least a partial liquidation of capital, rather than a mere expenditure of income.

For ecological economists, such cold fatalism is not cause for despair; it is cause for reform. Humanity is somewhat in control of the rate with which it advances entropic activity. A solar heated house only utilizes an infinitesimal fraction of the sun's several billion years of activity. A house heated by coal-fired electricity, on the other hand, transforms millions of years of condensed solar energy into greenhouse gases that persist in the atmosphere for decades. The economic argument for refusing to adopt the use of renewable energy sources immediately, on a widespread basis, is no longer as strong as it once was. The cost of solar cells has declined from more than $\$ 70$ per watt in the 1970 s to $\$ 4$ per watt today (in 1994 dollars), while the world market has grown from 34 megawatts in 1988 to an estimated 125 megawatts in 1997.100 The fastest growing energy market in the past decade has not been oil, coal, or natural gas, but wind power, growing

98 Se infra text accompanying notes 270-287.

99 Se infra text accompanying notes 25(;-287.

100 Christoplet Flavin, The Next Energy Retolution, in Tue Wordowatch ReAdek on Global. Environmen'tal Issues 56, 61 (Lesier R. Brown \& Ed Ayres eds., 1998). 
from 2000 megawatts in 1990 to 7600 megawatts in 1997,101 and remarkably achieving cost-competitiveness with its heavily subsidized, arguably unsustainable counterparts. ${ }^{102}$ But most of this development is occurring outside of the United States. Nations such as China, Mexico, Kenya, and Vietnam all currently use solar electrification to provide power to remote rural villages. ${ }^{103}$ In the view of ecological economists, nothing prevents industrialized nations such as the United States from doing the same besides entrenched political power and a failure to perceive the true costs of current practices. In light of this situation, Georgescu-Roegen's famous warning should be updated. It is not that Cadillacs prevent future spades and plows; it is that sport-utility vehicles prevent future wind turbines and solar cells.

\section{Optimal Scale and Sustainability}

The foregoing discussion establishes another of the foundational principles of ecological economics: "The macroeconomy is an open subsystem of the ecosystem and is totally dependent upon it, both as a source for inputs of low-entropy matter-energy and as a sink for outputs of high-entropy matter-energy." 104 Given such a conception, an inescapable question arises regarding how much the economic subsystem can grow before it places an unsustainable burden on the natural ecosystem. Conventional economists fail to address this issue because the macroeconomy is conceived of as the superstructure-conceptually, nothing exists "around" the macroeconomy. Thus, there is no reason to suspect that it cannot grow ad infinitum.

As Daly has noted, this failing is surprising given that every other economic concept involves a limit or point at which marginal benefits do not exceed marginal costs. ${ }^{105}$ More than one commentator has speculated that the disappearance of limits in macroeconomics serves as a theoretical expedient to avoid difficult questions of distribution. ${ }^{106}$ Instead of adopting such an approach, Daly argues that the

101 See id. at 57.

102 Cluristopluer Flavin \& Seth Dunn, Reinventing the Energy System, in SrATE of THE Wort.1) 22, 28 (Lester R. Brown et al. eds., 1999) ("Wind power is sow economically competitive with fossil fitel generated electricity, and the market, valued at roughly $\$ 2$ billion in 1998, is growing more than 25 percent amually.").

103 See Flavin, supra note 100; at 60.

104 See Daly, supra note 77 , at 35.

105 See DaLY, supra note 58, at 27.

100 See, e.g., idl at 7 (noting that the World Bank "catnnot acknowledge limits to growth because growth is seen as the solution to poverty"). 
logic of marginal analysis must apply with equal force to macroeconomics-that is, there must be a point at which the benefits from an increase in the scale of the economy are outweighed by the environmental and social costs entailed by such an increase. ${ }^{107}$ Economists and other thinkers interested in the welfare of humanity must therefore confront the issue of determining the optimal scale of the economy.

The most widely cited attempt to articulate a principle for limiting the scale of economic activity comes from the 1987 report of the United Nations World Commission on Environment and Development, popularly known as the Brundtland Report. ${ }^{108}$ This report urged nations to undergo only sustainable development, which it defined as development that "meets the needs of the present without compromising the ability of future generations to meet their own needs." 109 As Susan Smith has explained, two principles underlie this notion of sustainable development: "[T] he Earth's finite capacity to accommodate people and industrial development, and a moral imperative not to deprive future generations of natural resources essential to wellbeing and quality of environment." 110 Following the release of the Brundtland Report, several international agreements and statements of principles have further developed this goal of keeping human activity within the carrying capacity of the earth, including the Framework Convention on Climate Change, ${ }^{111}$ the Convention on Biological Diversity, ${ }^{112}$ the Rio Declaration, ${ }^{113}$ Agenda 21,114 and the Statement of Forest Principles. ${ }^{115}$

While these developments were initially viewed as an important step toward reaching a consensus to restrict the scale of the global economy, they have come under fire more recently for lacking the conceptual clarity needed to avoid unsustainable growth. Among ecological economists, Daly has been especially critical of the Brundtland

107 See id. at 27.

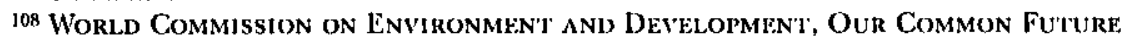
(1987).

${ }^{109}$ ld. at 8.

${ }^{110}$ Smith, supra note 72, at 262-63.

111 Framework Convention on Climate Change, 31 I.L.M. 849 (1992).

112 Convention on Biological Diversity, 31 I.L.M. 818 (1992).

115 Rio Declaration on Linvironment and Development, 31 I.L.M. 874 (1992).

1141 Agenda 21 and trit UCEd Procegdings, U.N. Confrrence on Environment AND DEvelopmen'r (Nicliolis A. Robinson ed., 1992).

115 Statement of Principles for a Global Consensus on the Management, Conservation and Sustainable Development of All Types of Forests, 31 1.L.M. 881 (1992). 
Report's ambiguity: "Sustainable development is a term that everyone likes, but nobody is sure of what it means." 116 Although the international community has agreed that it should not compromise the "needs" of future generations, it has not attempted to define what those "needs" will be. Should future generations be afforded only the natural resources necessary to maintain a basic level of subsistence? Should the "aesthetic" needs of the unborn be considered within the sustainable development rubric? What assumptions should be made about the ability of technological advancements to alleviate resource scarcities in the future? What type of allowance should be made for the limit of science's ability to recognize and assess the impact of economic activity on ecosystem viability?

By leaving these and other difficult questions unanswered, the Brundtland Commission was able to achieve broad support for its guidelines. However, because of the conceptual looseness inherent in the notion of sustainable development, and because of the wide disagreement over its proper interpretation, the principle can and has been co-opted by just about any group with an interest in the debate. ${ }^{117}$ At times, this co-opting results in advocacy totally divorced from the foundational principles of sustainable development, as when policymakers aspire to "sustainable growth in the rate of increase of economic activity." 18 Failing to understand that the Brundtland Report's thesis was that economic growth cannot continue indefinitely, these bullish thinkers advocate infinite acceleration in the rate of infinite growth.

In contrast to sucl vague verbiage, Daly has advocated the necessity of a "steady-state economy" in which the scale of human economic activity-that is, "the physical scale or size of the human presence in the ecosystem as measured by population times per capita resource use"119_does not exceed the point at which marginal macroeconomic benefits equal macroeconomic costs. ${ }^{120}$ Economists have typically ig-

${ }^{116}$ DALY, supra note 58, at 1 .

117 See id. at 2 ("Acceptance of a largely undefined term sets the stage for a situation where whoever can pin his or her clefinition to the term will automatically win a large political battle for influence over ou liuture.").

118 Herman E. Daly, Sustainable Grouth: An Impossibility Theorem (1990), reprinted in Valuing the Earth: Economics, Ecotogy, Etutcs 267, 269 (Herman E. Daly \& Kenneth N. Townsend eds., 1993).

119 DALY, supra note 58 , at 50.

${ }^{120}$ See id. at 3. The classical economist Mill supported a similar notion, which he called the stationary state, in which the size of a population and its capital stock remained constant while teclnological and culumal improvenents continued. See supra notes $27,38$. 
nored this type of marginal analysis at the macroeconomic level, opting to believe that micro-level consumption choices generally reflect Pareto improvements, and that therefore the aggregate of such choices must also reflect enhancements in social welfare. ${ }^{121}$ In Daly's view, however, prices only measure the scarcity of resources relative to each other. ${ }^{122}$ Micro-level choices may result in an efficient allocation of resources in relation to everything else, but they cannot determine an efficient absolute level of resource use. Therefore, just as full employment and fair distribution are macroeconomic goals that are not fully resolved by unfettered microeconomic activity, Daly believes that optimal scale is an issue that must be addressed by policy instruments operating on a macroeconomic level. ${ }^{123}$

"A necessary requirement for this optimal scale is that the economy's throughput-the flow beginning with raw material inputs, followed by their conversion into commodities, and finally into waste outputs-be within the regenerative and absorptive capacities of the ecosystem." 124 In other words, in order to be truly sustainable, the material scale of the economy must be within the carrying capacity of the earth. Giving flesh to the concept of "carrying capacity" is a challenging task that needs to be addressed before Daly's sustainable development can become a fully operable concept. Daly provides two fundamental principles toward that end: "Renewable resources should be exploited in a mamner such that: (1) harvesting rates do not exceed regeneration rates; and (2) waste emissions do not exceed the renewable assimilative capacity of the local environment. ${ }^{.125}$ Non-renewable resources should be depleted at a rate equal to the rate of creation of renewable substitutes. ${ }^{126}$

These principles of resource use, however, are only the first step in what is an essentially scientific exercise. Determining whether a given level of population and per capita resource use is sustainable

121 To be sure, econounists such as Nobel laureate Robert Lucas have developed the "microfoundations" of macrocconomics by exploring how the aggregation of individual rational behavior can impact (and indermine) Keynesian conomic theories. Sre V.V. Chari, Nobel Laurate Robert E. Lutas, Jr: Archilect of Modern Macoeconomics, 12 J. Econ. Persp. 171 (Winter 1998). They getlerally have not, however, asked the fitr more basic question that Daly is asking: whether an increase in total output costs more than it is worth. See infra text accompanying notes 132-172.

122 See Daly, supra note 58 , at 27.

123 See id. at 51.

124 Id. at 27-28.

${ }^{125}$ DALY, supra note 118 , at 271.

126 See id. at 271. 
requires the expertise of ecologists, biologists, and envirommental scientists, as well as economists. In Daly's view, the practitioners of economics should continue to practice their bread and butter of maximizing the market's allocative efficiency, but only after the optimal scale of that market has been determined by social consensus with input from both economic and noneconomic experts. ${ }^{127}$

A second task that is not exclusively economic involves determining the desirable mix of population size and resource intensity that will be used to consume society's annual quota of natural capital and services. As noted above, the scale or level of physical throughput in the economy can be thought of as the product of population times per capita resource use. ${ }^{128}$ This definition implies that a smaller population could lead a more resource-intensive lifestyle than a larger one, while staying within ecologically-imposed constraints of sustainability. Conversely, a larger population must reduce its per capita resource use in order to main tain the ecological footprint of a smaller one. Because the level of throughput must not be allowed to exceed the point at which ecosystem losses exceed economic gains, society must make a conscious tradeoff between these two determinant factors of the scale of its economy. Obviously, such a tradeoff entails a moral, not merely an economic, choice. Figure 1 summarizes the foregoing discussion.

Figure 1

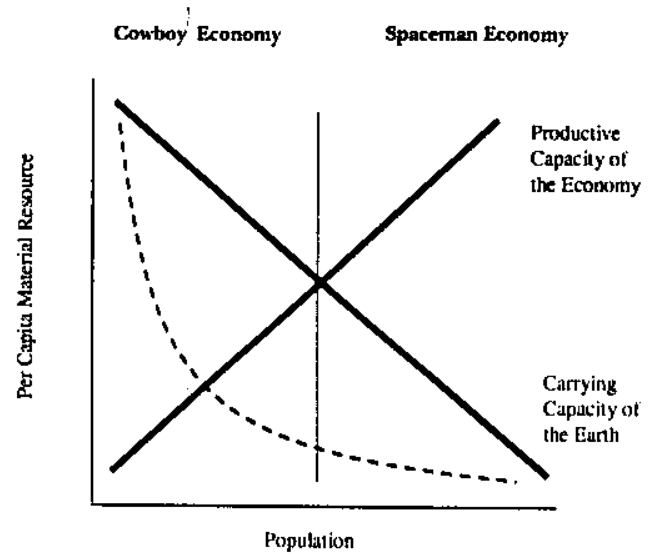

${ }^{127}$ See id. at $271-72$.

${ }^{128}$ See id. at 270. 
The $\mathrm{x}$-axis gives the earth's human population while the $y$-axis represents the per capita material resource use of that population. The product of these two factors gives the overall scale of material throughput in the econonin. Two bold lines are superimposed on the graph to represent constraints on the attainable level of throughput at any given population size: the productive capacity of the human economy and the carrying capacity of the earth. The former generally increases with population size, while the latter decreases. ${ }^{129}$ Daly's steady-state economy, in which throughput remains relatively constant and always within the carrying capacity of the enviromment, is represented by the dashed curve. A necessary implication of the steadystate economy is that as population increases along the curve, per capita material resource use must correspondingly decrease.

The majority of human economic history has occurred on the left half of the graph, in which the relevant limiting factor on throughput is not the carrying capacity of the ecological sphere, but instead the productive capacity of the human. This is Boulding's "cowboy economy" in which the logical goal seems to be relentless pursuit of increases in human economic production. ${ }^{130}$ Ecological economists, however, believe that humanity has now moved to the "spaceman economy" on the right half of the graph, in which human productive capacity has outstripped the carrying capacity of the earth; that is, the binding constraint on material throughput is no longer our capacity to produce, but the earth's capacity to generate resource imputs and absorb waste outputs. ${ }^{131}$ Here, society's challenge is to limit

129 The proluctive capacity of the luman economy generally increases with population size due to the increased avalability of labor and, to a less quantiliable extent, grealer opportunities for improvements in technology, skills, and knowledge. The carrying capacity of the earth decreases with population size, however, because the carlu's finite cnclowment of natural capital must be spread anong an ever-growing number of people. Note that this is not, strictly speaking, a Malthusian argunent. Maltlus believed that humanity would eventually face social and ecological ruin because it was incapable of checking population growtl. See generally Thomas Robert Malthus, An Essay on thil: Principle of Poputation (1798). History has of course proven Malthus wrong, at least with respect to a significant number of societies in the late twentieth century. See Reed Bolaud, The Environment, Population, and Women's Human Rights, 27 ENvTL. L. 1137, 1138 (1097) (noting that "Lplopulation stabilization thas been achieved in some thirty countries"). Ecological economists accept Malthus's premise that many natual resources cannot be teplicated exponentially in the way that population size can, but they emphatically reject the proposition that there is something incvitable about population growlh. Indecel, the very notion of regulating scale presupposes some ability on the part of society to regulate is population size (a primary determinant of scale).

130 See Boulding, supra note 28 , at 303.

151 See id. at 303. 
economic activity rather than maximize it, a task that will require vastly different cultural values and political tools than the growth obsession of the "cowboy economy."

It is important to note that intensity of material consumption need not be correlated with quality of life or welfare. Per capita material resource use is a scientific measure of the ecological impact of a society's consumption habits; it is not a measure of the value that the society derives from those habits. Put differently, it is quite possible that reductions in material resource use levels can result in increases in overall welfare. When a region switches from coal-fired to comparably priced wind-generated electricity, for instance, resource use per capita drops appreciably with little discernible influence on the consumer's lifestyle. If such reductions in resource intensity bring the region below the carrying capacity of the ecosystem, then the society can invest its newly created natural budget surplus in one of several ways. It can support a larger population at the same per capita resource use level, support the current population at a higher resource use level, or maintain both factors at current levels while deriving psychic benefit from the increased carrying capacity safety margin. Regardless of the region's choice, however, welfare will have inproved over the previous fossil fuel-based economy.

The central point is that welfare and resource intensity, although undoubtedly related, must still be analyzed as separate concepts. In the steady-state economy, it is of paramount importance that material throughput be maintained below limits imposed by the ecosystem. Welfare, however, can continue to grow as the economy focuses unprecedented attention on efficiency in the use of resources and the satisfaction of preferences.

\section{Measuring the Human Economy}

Economics is fundamentally a quantitative discipline. As Samuelson puts it in his renowned textbook, "economics focuses on concepts that can actually be measured. "132 Following the lead of John Maynard Keynes and Simon Kuznets, macroeconomists have focused exclusively on quantifying the productive capacity of the human economy.

132 See Clifford Cobb et al., If the GDP is Up, Why ls America Down?, 276 ATtantic Montily 59, 70 (1995) (quoling Paul A. Samuelson \& William D. Nordinus, EconomICs (16th ed. 1998)). Economist Joln Vaizey voiced a pervasive corollary to this principle: "I must confess to an instinctive conviction that what cannot be measured may not exist." Herman E. Daly \& Join B. Cobn, Jr., For the Common Good 31 (2d ed. 1994) (quoting John Vajzey, The Economics of Education 14 (1962)). 
However, as seen in the last Section, a second constraint on economic growth exists-the carrying capacity of the ecosystem. Moreover, even ignoring ecological limits to growth, there is little reason to suppose that increases in the sheer magnitude of the human economy are always desirable from the perspective of social welfare. Recognizing the practical worth of quantification (and the need to confront conventional economists in their own language), ecological economists have begun to focus attention on the task of measuring the intersection of economic and ecological spheres. This Section addresses the response of ecological economists to traditional indexes of social welfare such as the gross national product (GNP), while the next Section outlines efforts to quantify the value of the ecological sphere.

Current national accounting measures produce a variety of results that would strike noneconomists as odd. For instance, when the Exxon Valdez oil spill necessitated $\$ 2.1$ billion in clean-up costs, ${ }^{133}$ the U.S. GNP rose by that same amount, despite the fact that ten years later only two of the twenty-three most damaged wildlife species have recovered and $40 \%$ of area fishermen suffer depression over their destroyed livelihoods. ${ }^{194}$ Similarly, as Superfund contributors muster the $\$ 31$ billion needed to clean the 1355 worst locations on the E.P.A.'s list of nearly 40,000 hazardous waste sites, ${ }^{135}$ GNP views the expenditure as an increase in economic welfare, rather than just a restoration. GNP also ignores basic accounting principles by treating the unsustainable exploitation of natural capital as pure income. Centuries of logging and construction have resulted in the loss of all but $1 \%$ to $5 \%$ of the original forest cover of the United States, ${ }^{196}$ yet GNP has made no allowance along the way for the clepreciation of scarce natural capital.

Social as well as ecological costs frequently appear as gains under GNP accounting. When the estimated one third of American adults

135 See Scoit Allen, Deep Problems 10 Years Afler Exxon Valdez: Worst Oil Spill in US Has Lingeving Effects for Alaska, Industries, Boston Glowe, Mar: 7, 1999 (page w1available).

134 See id.

iss See Environmental. Protrction Agency, 1994 Superfund) Annual Rejor't 'to Congress $41-43,129$ (1994).

1.96 See Janet N. Alranmovitz, Nature's "Free" Services, in Worl.dwatch Reaner on Glohat. Environmental Issues 150, 155 (Lester R. Brown \& Ed Ayres eds., 1998). Although much of the United States has been "reforested," such monocultural plantations provide an imperfect substitute for the ccological functions performed by diverse old growth forests. See G. Gordon Davis, Land Use Planning in Furtherante of Stustainable Dezelopment in Asin, 3 WIDENex L. SYMP. J. 119, 135-36 (1998) (noting that converting a maltual forest to a tree farm wonld impair the carying capacity of the supporting ecosystem"). 
who are obese spent $\$ 39$ billion in one year on health care costs for obesity-related diseases, ${ }^{137}$ the macroeconomic indicators recorded an unmitigated credit. When the position of the United States as home to 1.7 million prisoners and the largest incarceration system in the world necessitated a doubling of state spending on prisons in the last decade, ${ }^{138}$ GNP rose to reflect the social "progress" of unprecedented prison construction. And when the American divorce rate doubled between 1970 and the present, ${ }^{139}$ GNP recorded an increase from the real estate transactions, attorney bills, and other expenditures necessitated by the higher number of family fractures. ${ }^{140}$

Such arguably counterintuitive results are an outgrowth of the "cowboy economy" in which more of anything is simply better, regardless of what it is. Standard national accounting measures such as GNP, and more recently gross domestic product (GDP), seek only to quantify the value of monetary transactions that occur in a given economy, with no distinction among purposes and no recognition of adverse consequences that result from such transactions. No allowance is made for the irreversible depletion of natural resource inputs, or the externalized costs of waste outputs. Indeed, such environmental costs are frequently treated as economic gains, leading to a perverse national incentive structure: A policy of maximizing GNP is "practically equivalent to a policy of maximizing depletion and pollution." 141

Nor is any accounting attempted of other "noneconomic" spheres such as the livelihood of conmunities, the stability of families, or the safety of schools. Unexamined pursuit of increases in GNP can lead to parasitic growth. Commercialization of social functions traditionally performed outside the economic sphere-such as the replacement of stay-at-home parenting by child care, prepared meals by . convenience food, social networks by self-help tapes, and community

${ }^{137}$ Scolt Petersen, Discrimination Against Overueight People: Can Society Still Get Away with Il, 30 Gonz. L. Rev. 105, 108 (1994).

${ }^{134}$ Jonathan Kanfman, Frustration With Crime Wave, and Criminals, Led To a Huge Surge in the Constraction of Jail Cells, WaL.L ST. J., Oct. 27, 1998, at Al8.

${ }^{139}$ See Maggie Gallagher, Fatherless Boys Grow Up Into Dangerous Men, WALL. St. J., Dec. 1, 1998 , at $A 22$.

${ }^{140}$ Similar examples alomud. See, e.g., Colsb et al., supra note 132 , at $70-72$ (citing crine, divorce, mass-media addicion, natural disaster relief, and other examples of anomalous "growth"); Herman E. Daly, Introduction to Essays Toward a Steady-State Economy, reprinted in Valuing tue Eak'ti: Economics, Ecology, Ethics 11, 40-41 (Herman E. Daly \& Kenneth N. Townsend eds., 1993) (noting that the medical bills necessitated by cigarette induced cancer and pollution induced-emphysema are added to GNP, and calling such expenditures "swelling, not growth").

it Dat., supra note 58, al 41. 
activities by commercial entertainment-is a consequence encouraged by any national agenda that seeks to maximize GNP.

Nobel Prize-winning economist Simon Kuznets, one of the chief architects of the concept of GNP, warned that the measurement of GNP should never be mistaken for true national progress: "Distinctions must be kept in mind between quantity and quality of growth, between its costs and return, and between the short and the long rum. Goals for 'more' growth should specify more growth of what and for what." 142 Many policymakers, however, have largely ignored this advice, seeking continual, indiscriminate growth in GNP as the ready salve for all manner of national problems. Ecological economists, on the other hand, have criticized GNP as a concept that fosters unsustainable economic practices while failing to achieve its aim of approximating human welfare. In its stead, Daly and theologian John Cobb, Jr., have offered a substitute national wealth accounting measure that corrects for many of the GNP's failings. ${ }^{143}$

Called the Index of Sustainable Economic Welfare (ISEW), Daly and Cobb's measure begins with total consumption expenditure data gathered by the U.S. Bureau of Economic Analysis and then proceeds to make a series of adjustments to arrive at a best estimate of sustainable economic welfare. The first adjustment, for income inequality, attempts to account for the fact that "an additional thousand dollars in income adds more to the welfare of a poor family than it does to a rich family." 144 This notion, which many accept as a consequence of the principle of diminishing marginal utility of income, has important implications for the calculation of economic welfare. If income distribution becomes more uneven over a period of time, unadjusted dollar flows for that period will overstate welfare. To correct for this dis-

142 Cobb et al., supra note 132, at 67 (quoting Kuznets).

145 See DALY \& Con13, supra note 132, at 443-507. Many others have conducied similar exercises. Robert Eisner, for instance, has been championing a major reform of national income accounting for two clecacles. Sce Robert Eisner, The Total Incomes System of Accounts, 65 Surv. of Current Bus. 24, 24-48 (1985); Robert Eisner, Total lincomes in the United States, 1959 and 1969, 24 Rvv. of Income \& WeAlTu 41, 41-70 (1978). Even before Eisner; William Nordhaus and Janes Tobin discussed the adjustment of GNP for a variety of factors, including correction for cerlain disamenities of urbanization, reclassification of expenditures into consumption, investment, and intermediate categories, and inputation of service value from consumer durables, leisure, and household work. See Willian Nordhus \& James Tobin, Is Grouth Obsolete?, in Economic Growrit I (National Bureau of Economic: Research ed., 1972).

144 DALY \& CoBB, supra note 132, at 445. 
tortion, Daly and Cobb alter consumption expenditure data to reflect the degree of income inequality in the economy. ${ }^{145}$

Next, Daly and Cobb add factors representing positive income streams from four sources that are currently absent from official consumption data-household labor, ${ }^{146}$ existing consumer durables, ${ }^{147}$ public streets and highways, ${ }^{148}$ and public spending on health and education. ${ }^{149}$ Conversely, deductions are made for expenditures that arguably do not contribute to improvement in economic welfare. For example, a portion of private spending on education is deducted to represent the "competitive" nature of such spending. ${ }^{150}$ Similarly, the authors disallow some private expenditures on health care because they view them as attributable to "growing health risks due to urbanization and industrialization." 151 Other costs deducted from total ex-

${ }^{145}$ See id. at 464-65. The authors achieve this adjustment by using an income inequality index in which the disuibution of income in 1950 serves as a neutral baseline. See id. at 465. Thus, when income inequality decreased during the 1960s, ISEW rose. Conversely, when greater inequities in income distribution occurred during the mid-1970s and 1980s, ISEW fell. See id. at 493 .

${ }^{146}$ See id. at 458.

${ }^{147}$ Current national accounting systems simply calculate all expenditures on consumer durables as current income, rather than attempting to separate the transactions into a capitial expense and an income stream. This leads to the ironic result that shoddy products necessitating rapid replacement indicate rising economic "welfare." See id. at 466. Daly and Cobl) take the more approprate accounting approach of treating spending on consumer durables as a capital investment; thus, they exclude current consumer durables expenditures but impute an anmual income component to the total measure of economic welfare.

1 to See id. at $467-68$.

${ }^{149}$ See $i d$. at 468-69. The authors do not count all of public health and education expenditures because they view much of the costs as "defensive" in nature. Citing Lester 'Thurow's model of education as a sorting mechanism to signal "trainability" rather than enhauced productive skill, see lester C. Thutow, Education and Economic Equality, in TuE "INLQuality" Controversy: Schtuoling and Distrubutive Justice 170, 172 (Domald M. Levitue \& Mary Jo Bane eds., 1975), Daly and Cobb argue (hat much of education speuting represents an attempt to maintain competitive employment status, rather than an actual improvement in the stock of luman capital. "In other words, people attend school because the failure to attend would mean falling behind in the competition for diplomas or degrees that confer higher incomes on their recipients." DALY \& CовB, supra note 132, at 468 .

This aspect of Daly and Cobb's calculation is open to considerable challenge. Even if competitive educational expenditures fail to increase one's relative position in society and fitil to increase national productivity, there still may be an intrinsic benefit from educational experience that accrucs to the individual and stould be counted as a contribution to social welfare. In other words, Daly and Cobb's view of education as requiring tangible benefits to be considered welfareenhancing may be an example of the same narrow economic perspective that they are attempting to reform.

150 See supra note 149.

151 DaLy \& CoBB, supra note 132, at 469. 
penditures because of their "defensive" nature include the costs of commuting, ${ }^{152}$ purchases of personal pollution control equipment such as air and water filters, ${ }^{159}$ and damages due to vehicular accidents. ${ }^{154}$

Having attempted to refine the calculation of economic welfare in accord with certain social realities, Daly and Cobb then turn to the realities of the environment in relation to the economic subsystem. They first deduct amounts relating to the current envirommental damage imposed by economic activity, including the annual cost of water pollution, ${ }^{155}$ air pollution, ${ }^{156}$ noise pollution, ${ }^{157}$ loss of wetlands, ${ }^{158}$ and loss of farmland. ${ }^{159}$ These costs are the least controversial of Daly and Cobb's estimates of envirommental damage, as they represent tangible, present costs with little scientific dispute as to their existence. ${ }^{160}$ Moreover, the authors adopt a purposefully conservative approach to valuation of these costs. For instance, they do not include the costs of water pollution from nonpoint sources ${ }^{161}$ or the healthrelated costs of air pollution. ${ }^{162}$

The authors also attempt to account for the long-term environmental costs associated with economic activity. First, Daly and Cobb recognize that the consumption of nonrenewable resources constitutes in part "a cost borne by future generations that should be subtracted from (debited to) the capital account of the current genera-

152 See id. al $469-70$.

153 See id. al 470.

154 See id. at 471 (calling such cxpenses a "real cost of industrialization and higher traffic densities").

155 See id. at 471-74.

156 DALY \& Col313, supra no1e 132, at 474-77.

157 Sice id. at 477.

${ }^{158}$ See id. at $477-78$.

${ }^{159}$ See id. al 478-82.

${ }^{160}$ Although causation may not be scientifically contested, valuation is always a difficult issue. See id. at 471 .

161 Da1, \& Conb, supra note 132, al 471.

162 Sre id. at 475-76. Nevertheless, some might contend that at least some of Daly and Cobb's current environmental costs to not impact overall welfare. For instance, some might argue that the loss of wetlants and farmand should not be considered an economic: cost as these areas are likely being converted to other economically productive purposes. Regardless of the purpose for which the land is developed, however, there are still real costs associated with conversion inasmuch as humans have no reliable substitute for many of the services provided by wetlands and farmlands. Thus, if one is to credit the consumer dollars spent at a new subutban shopping mall, then one must also clebit the irretrievable loss of arable land that was covered in the process. Daly and Cobb are merely attempting to arrive at a net figure for the value of industrialization-any other approach would provicle a less than full dejiction of ecomomic welfare. 
tion." 169 To price this cost, the authors rely on the marginal cost of producing a renewable substitute: "For each unit of nonrenewable resource depleted, we have estimated the amount of money that would have to be invested in a process to create a perpetual stream of output of a renewable substitute for it. "164 Second, Daly and Cobb undertake the daunting task of estimating the economic impact of longterm build-up of thermal waste in the environment. ${ }^{165}$ Such accounting is of course destined to be inexact, but Daly and Cobb's rough approximation seems at least preferable to the alternative of measuring the costs of global warming and ozone depletion at precisely zero. In a final set of adjustments, Daly and Cobb alter ISEW to account for changes in the domestic and international capital position of the national economy. 166 These adjustments reflect the fact that current economic welfare can be maintained only if growth in the domestic capital stock keeps pace with population growth.

The foregoing calculations are summarized in Table 1, using the year 1990 as an example. ${ }^{167}$

Table 1-Index of Sustainalıle Econonic Welfare

United States-1990 (measured in billions of constant 1972 dollars)

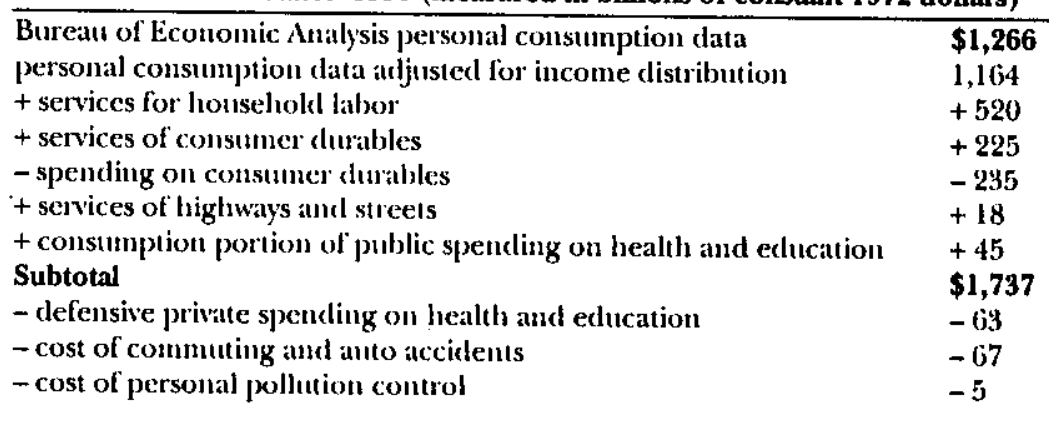

163 Id. at 482.

16 Id. at 484. Daly and Cobb use the production cost of ethanol, a plantederived substitute for many uses of oil. See id. at 485. Given the difficulties of producing ethanot on a large scale, lowever; the author's selection might overstate nonrenewable depletion costs as against other renewable energy sounces that are less costly to produce and can replace oil in certain applications.

165 In particular, the atthors attempt to assign a dollar figure to a hypothetical anmual set-aside that would be recuired to compensate future generations for the costs associated with global climate change. See id. at 489-90. A similar melhodology is used with respect to the production of chlorofluorocirbons and other ozone-depleting gases. See id. at 490.

166 Daly \& Co1313, stema note 132, at 491-92.

${ }_{167}$ This lable is clerived from il. al 462-63, tbl.A.l. The total cliffers from the sum of the individual items clue to rounding. 
Table 1-Index of Sustainable Economic Welfare

\begin{tabular}{lc}
\hline \multicolumn{1}{c}{ United States-1990 (measured in billions of constant 1972 dollars) } \\
\hline - cost of current environmental pollution & -39 \\
- loss of wetlands and farmuland & -58 \\
- depletion of nonrenewable resources & -313 \\
- cost of long-term envirommental harms & -371 \\
+ net capital growth & +29 \\
+/- change in net international inves(ment position & -34 \\
Index of Sustainable Economic Welfare & $\$ 818$ \\
\hline
\end{tabular}

As one can see, while the first subtotal of ISEW showed a consumer gain of $\$ 1737$ billion for 1990 , the end result revealed only $\$ 818$ billion in net economic welfare created during the year. One can think of the $\$ 919$ billion differential as a very rough estimate of the total cost of environmental and social externalities created by economic activity in 1990. Given that this amount is actually greater than the net value created that year, it is arguably an analytical strain to continue to refer to envirommental and social costs as mere "externalities," a term suggesting only minor effects of limited interest. To the contrary, under Daly and Cobb's calculations, externalities appear to be a dominant effect of market transactions, suggesting that "it is time to restructure basic concepts and start with a different set of abstractions that can embrace what was previously external."168

Contrasting the ISEW with GNP over a time series is also revealing. According to Daly and Cobb, GNP and ISEW both rose from 1951 until the 1970s (although the rate of growth in ISEW decreased from $1.57 \%$ to $0.21 \%$ between the $1960 \mathrm{~s}$ and $1970 \mathrm{~s}$ ) ${ }^{169}$ In the $1980 \mathrm{~s}$, however; GNP continued to rise while ISEW actually declined by $0.43 \%$ per year: ${ }^{170}$ This decline suggests that continued increases in the scale of the human economy (as approximately signaled by increases in GNP) are anti-economic; that is, they impose more welfare costs than benefits (as signaled by decreases in ISEW). Thus, beginning in the late 1970 s and early $1980 \mathrm{~s}$, the United States may well have shifted from the cowboy to the spaceman economy, with all its attendant problems.

Of course, Daly and Cobb's figures are easily contestable, as would be any attempt to track and price the total social and environ-

$168 \mathrm{Id}$, at 37. It is also interesting to note that a capilalist cconomy featuring such massive externalities becomes, in some respects, an economy of chaotic socialism. Externalized costs are borne ultimately by the public-in effect, they are socialized-but without even the minimal benefit of the central planting efforts associated with socialism.

169 Id. at $462-63$, tbl.A.l.

${ }^{170} \mathrm{Id}$ 
mental costs of human economic activity. Nevertheless, even without deducting for resource depletion and long-term envirommental costs-the two most controversial and difficult to quantify aspects of ISEW-the pattern of change in ISEW remains largely the same. ${ }^{171}$ This suggests, at an absolute minimum, that undifferentiated growth in GNP is not necessarily consonant with economic welfare and that reliance on GNP as a measure of national success should be reevaluated. ${ }^{172}$

\section{Valuing Ecosystem Services}

In addition to reforming the measurement of national accounts, ecological economists have also devoted significant attention to quantifying the worth of ecosystem services. The attempt to place a monetary value on the elements of nature has long been controversial. Many view such attempts as an almost heretical failure to appreciate that nature is "priceless." Rutgers University biologist David Ehrenfeld provides a representative, if charged, example of this view: "I am afraid that I don't see much hope for a civilization so stupid that it demands a quantitative estimate of the value of its own umbilical cord." 178 Others attack the practice from the opposite extreme, believing that the survey methods frequently used to price natural resources are fraught with complexities that render valuations wildly overstated. ${ }^{174}$ Nevertheless, economists, policymakers, and courts continue

171 See id. at 505.

172 Redefining Progress, a think tank specializing in the use and improvement of economic indicators to guide sustainable policy solutions, has continued Daly and Cobb's work in the years following 1990. That organization's index, clibbed the Genuine Progress Inclicator (GPI), is similat to the ISEW' but adds acljustment categories for such factors as volumteer work, leisure time, crime, and underemployment. The GPI portrays the 1990s as slipping even further away fiom sustainable economic activity:

Overall, the decline of the GPI in the 1990s has been the most rapid in five decades. It suggests that the recent financial boom, with the associated shopping spree, has masked an erosion in the real econony that the conventional indicators hide. Increasingly the U. S. is living off its capital-social and envirommental as well as financial. In the parlatice of policy experts, the economy has become rife with "unintended consequences," as well as intended though unspoken oncs.

Jonathan Rowe \& Mark Anielski, Genuine Progress Indicator 1998: Executive Summary, avaiiable at lıtp://www.rprogress.org/publications/gpi1998/gpi1998_execsum.html (last modilied Mar. 1999).

175 Gersli, supra note 71 , at 36.

17.4 See Brian R. Binger et al., The Use of Contingent Valuation Methodology in Natural Resource Damage Assessments: Legal Fact and Economic Fiction, 89 Nw. U. L. REv. 1029 (1995); 
to place economic values on natural resources through the use of such techniques as restoration or replacement cost valuations, travel cost valuations, hedonic pricing, and contingent or willingness-to-pay valuations. ${ }^{175}$

Commonly, the practice of commodifying nature occurs in the context of calculating after-the-fact damages awards for. contamination of natural resources. ${ }^{176}$ Ecological economists have recently adopted a different approach, seeking to quantify the value of services provided by ecosystems before irreversible human disruption. ${ }^{177}$ The significance of focusing on ecosystem services, rather than natural resources, is that they are seen by researchers as largely irreplaceable and therefore more fundamental to human survival. Moreover, while the economy may be able to signal and adjust to specific resource scarcities, the services provided by the earth are generally not subject to economic signaling. ${ }^{178}$ Thus, in order to ensure the long-term sustainability of human economic activity, ecological economists believe that natural services which lack practical man-made substitutes should be given a quantified presence within economic decisionmaking. By generating even approximate figures for the value of these services, ecological economists hope to impress upon private and public decisionmakers the environmental costs of contemplated development schemes.

A celebrated example of such thinking can be seen in the City of New York's decision to reclaim watershed areas in the Catskills mountains rather than 'build a capital-intensive water treatment facility. ${ }^{179}$ The Catskills have long been the primary source of purified water for New York City, but in recent years the water failed EPA standards for drinking water due to development in the mountains as well as increased sewage, pesticide, and fertilizer contannination. ${ }^{180}$ The city estimated that a purification plant would cost $\$ 4$ billion to build plus annual operating costs, while restoring the natural integrity of the

Note, "Ask A Silly Question ... ": Contingent Valuation of Natural Resource Damages, 105 HARv. L. Rev. 1981 (1992).

${ }^{175}$ See Frank B. Cross, Natural Resoure Damage Valuation, 42 VAND. L. REv. 269, 297-320 (1989).

176 See id. at 273.

177 A recent issue of the Stanford Envirmmental Lau Joumal contained several articles on the concept and measurement of ecosystem services. See, e.g., James Salziman et al, Protecting Ecosystem Services: Science, Economics, and Lazl, 20 STAN. ENv'?L L.J. 309 (2001).

178 See infra text accompanying notes 234-252.

179 See James Salzman, Valuing Ecosystem Services, 24 Ecol.ocy L.Q. 887, 893 (1997). 180 See id. 
Catskills through land acquisition and restoration would cost only around $\$ 660$ million. ${ }^{181}$ Thus, the City decided to invest in "natural capital" as a more efficient and aesthetically desirable alternative to the traditional industrial solution.

The City of New York's choice was easy to make because the treatment plant option provided a clear and reliable measure of the worth of the Catskills watershed services. As James Salzman has noted, "Replacement cost provides an effective method for valuing services because one can compare dollar investments in natural capital and physical capital to determine payback periods and overall costs."182 Ecological economists believe that if valuations of ecosystem services are available to policymakers at crucial decision times in that manner, economic development will become much more consonant with sustainable use patterns. For instance, researchers studying alternative management strategies for mangrove forests in Indonesia have found that when nontimber uses, including fish, locally used products, and erosion control, are included in cost-benefit calculations, sustainable timber practices are significantly more economic than traditional ones, yielding $\$ 4,800$ per hectare rather than merely $\$ 3,600.183$

Stanford University biologist Gretchen Daily edited a collection of studies performing just this type of analysis. Entitled Nature's Services: Societal Dependence on Natural Ecosystems, the compendium gathers valuation essays by ecologists and economists on such diverse ecosystem services as air and water purification, watershed maintenance, waste treatment, biodiversity regulation, climate stabilization, crop pollinization, pest control, and soil renewal. ${ }^{184}$ To give just one example of their findings, the researchers estimate that if the nitrogen content of soil provided by existing natural processes had to be supplied by commercial fertilizer, the lowest-cost estimate for its agricultural use in the United States would be $\$ 45$ billion per year, and for all land plants worldwide, $\$ 320$ billion. ${ }^{185}$ Human activities that disrupt the provision of natural services-such as the impairment of nature's $\$ 320$ billion annual production of nitrogen by industrial farming

181 See id.

182 Id. at 894 .

${ }^{183}$ See Abramovitz, supra note 136 , at 156.

184 See Nature's Services: Societal Dependence on Natural Ecosystems (Gretchen C. Daily ed., 1997).

185 See Gretchen C. Daily et al., Ecosystem Services Supplied by Soil, in Nature's SERvices: Societal Dependence on Natural Ecosystems 113, 125 (Gretchen C. Daily ed., 1997). 
techniques-should have a tangible price placed upon them, however imperfect, to reflect their ecological effects.

Subsequent work by an international team of researchers led by University of Maryland ecological economist Robert Costanza calculated an estimate of the economic value provided by the earth's ecosystems in their totality. ${ }^{186}$ The researchers estimated values for seventeen essential services provided by sixteen types of ecosystems around the world, including open oceans, coastal areas, lakes and rivers, croplands, deserts, forests, and grasslands. ${ }^{187}$ Their total figure for the worth of global ecosystem services ranged from $\$ 16$ trillion to $\$ 54$ trillion annually, providing an estimate of nature's macroeconomy that rivals or exceeds gross world product. ${ }^{188}$

Of course, in their totality, ecosystem services consist of the very ability to support human life, rendering their aggregate value equivalent to the very value one places on human existence. Economic tools are simply not designed to measure such concepts. By attempting to price the various subcomponents of ecosystems, however, ecological economists have begun to speak in a language that economists and policymakers can fathom and operationalize. As the Catskills watershed and Indonesian mangrove examples point out, the resulting dialogue can yield surprising agreement between environmental and economic interests. The Economists' Statement on Climate Change, signed by over 2500 economists, including eight Nobel Laureates, offers an unqualified endorsement of such collaborative exercises in the context of reducing greenhouse emịssions: "[S]ound economic analysis shows that there are policy options that would slow climate change without harming American living standards, and these measures may in fact improve U.S. productivity in the longer run." 189 Ecological economists believe that such "sound economic analysis" can become commonplace in the debate over competing business and environmental concerns.

${ }_{186}$ See Robert Costanza et al, The Value of the World's Ecosystem Services and Natural Capital, 387 NATURE 253 (1997).

187 See id, at 256.

188 See id, at 259.

${ }^{189}$ Redlefining Progress, Economists' Statement on Climate Changr, anailable at Lit1p://www. rprogress.org/publications/econstatement.htm] (last visited October 22, 2001). 


\section{Discount Rates and Intergenerational Equity}

A final issue of concern to ecological economists is the use of discount rates in regulatory and investment decisionmaking. ${ }^{190}$ When evaluating a particular investment decision, economists typically reduce expected costs and benefits to present value using a discount rate, or a percentage factor that adjusts the amount of a value over time. For instance, using a discount rate of $10 \%$, an investment yielding $\$ 110$ in year two is worth only $\$ 100$ in year one. If the investment costs $\$ 105$ to make in year one, it is not an economic choice. Such reasoning holds well in the context of paper investment decisions. However, when the expected yield consists of saved lives, preserved ecosystem services, and other nontangible benefits to present and future generations, it is not altogether obvious that the same analysis should apply. Nevertheless, economists have long taken discounting to be the appropriate response to questions of environmental importance. As early as 1913 , economists noted that " $[t]$ he primary problem of conservation, ... expressed in economic language, is the determination of the proper rate of discount on the future with respect to the utilization of our natural resources." 19 !

Frequently, discount rates are determined based on the prevailing real rate of interest charged in capital markets. ${ }^{192}$ However, positive interest rates, which can be said to represent the growth potential of mant-made capital, are a poor indicator of the growth potential of natural capital. The fact that capital may grow in a bank at $10 \%$ per year does not necessarily imply that an old growth forest will regenerate at an equal rate. A timber company adopting a $10 \%$ discount rate to determine harvesting schedules will "rationally" clear forests faster than they can regrow, essentially liquidating the natural capital of the forest rather than consuming only its annual income. In this manner, use of positive discount rates in development strategy can lead to an "optimal" choice that is unsustainable-"the impoverishment of future generations as a result of the profligacy of present generations in

190 This issue also has achieved great salience anong legal scholitus. See, e.g., John J. Donolute III, Why We Should Discount the Vieus of Those Who Discount Discounting, 108 Yal. L.J. 1901 (1999); Lisa Heinzerling, Discounting Life, 108 YALE L.J. 1911 (1999) [hereinafter 1. Ieinzerling, Discounting Life]; Lisa Heinzerling, Discounting Our Future, 34 LAND \& WaTER L. Rev. 39 (1999); Lisa Heinzerling, Environmental Law and the Present Future, 87 Gro. L.J. 2025 (1999); Richaud L. Revesz, Envionmental Regulation, Cost-Benefit Analysis, and the Discounting of Human Lives, 99 CoLUM. L. REv. 941 (1999) .

191 L. C. Gray, The Economic Possibilities of Conservation, 27 Q.J. Econ. 497, 515 (1913).

192 See Revesz, supra note 190, at 977-81. 
such cases is not just an incidental, but a desirable outcome of the decision making process." 193

Besides encouraging unsustainable investment strategies, discounting can also discourage ecologically desirable government regulations. Because society must often pay the costs of environmental regulation long before the benefits accrue, discounting of future costs and benefits frequently counsels against the adoption of environmentally-protective measures. Daniel Farber and Paul Hemmersbaugh provide an extreme illustration by positing the case of two alternative designs for a nuclear waste repository. ${ }^{194}$ The designs will cost the same amount and will both be paid for entirely in the first year. If the first design is adopted, no workers will be killed during construction but one billion people will be killed in five hundred years due to a radiation leak from the repository. If the second design is adopted, between one and two workers will likely be killed during construction but no leaks and therefore no deaths will occur in five hundred years. Using a discount rate of $5 \%$, the regulator selecting between designs "will choose the first option because one billion lives 500 years hence have a lower present value than one life today." 195 Similar reasoning applies in less extreme, more common settings. Preventing greenhouse gas emissions, water contanination, species extinction, resource depletion, and many other environmental harms imposes current costs while offering mainly future benefits. As such, the measures routinely fail cost-benefit analyses that use a high positive discount rate.

Still, though, the impact of discounting on the environment is difficult to generalize. As Daly has pointed out, high positive discount rates can have two competing effects on natural resource exploitation. ${ }^{196}$ Although a high rate will shift the allocation of capital and labor to projects that exploit resources more quickly, the rate will also limit the total number of projects that are undertaken given that $\mathrm{cx}$ pected project benefits inust overcome a higher opportunity cost value. Conversely, a low discount rate may slow the rate of resource extraction, but it may also increase the total number of extractive pro-

193 Charles Perrings, Reserved Rationality and the Precantionary Principle: Technological Changr, Time and Uncotainty in Entironmental Decision Making, in ECotogical. Econonucs: 'Itim Science and Manacimint of Sustainalility 153, 155 (Robert Coslanza ed., 1991).

194 Daniel A. Farber \& Paul A. Henumerslyangl, The Shadow of the Future: Discount Rates, Later Generations, and the Environment, 46 VAND. L. REv. 267, 290 (1993).

$195 \mathrm{Id}$.

190 See Daly, supra note 58, at 50-51. 
jects undertaken by making the projects appear more economic. ${ }^{197}$ Thus, the total effect of discounting on the enviromment is ambiguous, leading to what Richard Norgaard and Richard Howarth have called "the conservationist's dilemma."198

Norgaard and Howarth have attempted to solve this dilemma by separating the questions of intragenerational resource allocation, for which discounting is an appropriate policy tool, and intergenerational resource distribution, for which discounting is not. ${ }^{199}$ Economists frequently recognize that unfettered market outcomes will not necessarily result in a just distribution of resources between generations, just as they do not necessarily result in distributive justice within generations. Stiglitz, for instance, noted that " $[t]$ here is . . no presumption that the intertemporal distribution of income which emerges from the market solution will be 'socially optimal . . .'"200 Most economists, however, believe that the use of a discount rate is sufficient to solve the problem of intergenerational equity. As Stiglitz put it, "if the government correctly controls the rate of interest ... then there would be no objection to the competitive determination of the rate of utilization of our natural resources." 201

However, as Norgaard and Howarth point out, the discount rate cannot simultaneously serve the purpose of intragenerational allocative efficiency and intergenerational distributive equity. As noted above, ${ }^{202}$ governments often look to market rates of interest in setting discount rates for policy proposals, yet interest rates, like prices, quantities, and other market outcomes, are dependent upon the initial distribution of resources, including intergenerational distributions. "Since all of the variables that go into the calculation of net present value of a project or policy proposal depend on the intergenerational

197 See id. att 50.

198 Richard B. Norgaard \& Richard B. Howarth, Sustainability and Discounting the Future, in Ecological. Economics: Tite Science and Management of Sustainability 88,90 (Robert Costariza ed., 1991).

199 See id. at 88-101. In an especially lucid article on the issues posed by discounting, Ricluard Revesz has proposed a similu demarcation between esvitonmental regulation benefits that accrue to current and future generations. See Revesz, supra note 190, at 947. 48. Like Norganal and Howath, he conchues that discounting is only justifiable in the former case. For intergenerational clecisionmaking, Revesz proposes a "theory of intergenerational obligations" that combines elements of sustainability, distributive justice, corrective justice, ancl opportunity cost criteria. See id. at 1015-16.

200 Josepli Stiglitz. Growth anith Exhaustible Natural Resoures: The Competitive Economy, 41 REv. Econ. Srud. 139 (1974).

$201 / d$. at 139.

202 See supra texi accompanying note 192. 
distribution of income, what might appear to be a good social investment under one income distribution may be marginal or worse under another. ${ }^{203}$ In other words, relying upon market rates of interest to guide social policies affecting intergenerational resource distribution presupposes the very judgment to be made.

Because he recognizes that discounting acts as a subtle proxy for important decisions of intergenerational equity in this manner, ${ }^{204}$ famed economist Robert Solow has suggested that the discount rate should be determined directly by society rather than by reference to market interest rates. ${ }^{205}$ Selection of a social discount rate, however, must be determined in large part by society's view of the initial intergenerational distribution of resources. Following selection of the rate, a new equilibrium will emerge in which resources are distributed differently among generations. That new equilibrium will cause the current generation to reconsider its choice of the appropriate discount rate, which will result in still another equilibrium, and so on.

Thus, relying upon use of a discount rate to automatically "correct" the problem of intergenerational distribution is problematic, no matter how the rate is determined. Intergenerational distributive questions are rate-determining, not rate-determined. In other words, the decision whether to curtail greenhouse emissions should depend directly on whether society wishes to risk depriving future generations of climate stability, not on whether the discount rate will permit it to happen. As Norgaard and Howarth put it, "Questions which are fundamentally matters of equity should be treated as such." 206

Returning to Farber and Hemmersbaugh's example helps to illustrate these considerations. On the standard approach, if a proposed regulation would save the lives of one billion people five hundred years from now, the value of those lives is discominted to a present value. In essence, economists attempt to measure what it is worth to society now to save the lives of a billion people in the future. As Farber and Hemmersbaugh demonstrate, it turns out not to be worth very much. However, the use of the present generation's valuation of the

${ }^{203}$ Norgatircl \& IIlowath, supma note 198, at 97-98.

${ }^{204}$ Robert M. Solow, The Econonics of Resoures or the Resources of Economics, 64 AM. EcoN. Rfv. Papers \& Phoc. 1, 10 (1974) ("Ilic choice of a social cliscomt rate is, in elfect, a policy decision about ... intergencrational distribution.").

205 Id. Indeed, Solow argues that "no generation "should" be favored over iny other;" and that instead discounting shonk! be viewed as simply a "concession to human weakness ...." Robert Solow, An Almost Practical Step Toward Sustainability, 19 Resourcis Pon'y 162, 165 (1993).

${ }^{206}$ Norgaard \& Howarth, supra note 198 , at 98. 
worth of a future generation's lives is a normative judgment that should not be obscured by arithmetic. As Lisa Heinzerling powerfully put it, "Generating numbers that are ultimately irrelevant to the questions to be resolved does more than waste precious regulatory resources. It changes the apparent nature of the decision itself, and permits politics and ideology to hide behind a mask of technical expertise." ${ }^{207}$

\section{Summary}

The foregoing discussion provides an overview of fundamental concepts and methodologies in ecological economics. Beginning with the principle that the environment's capacity to regenerate resources and absorb wastes is limited, ecological economists argue that the scale of the human economy also must be subject to limits if it is to be sustainable over time. At some point, possibly already reached, economic expansion necessarily creates more environmental and social costs than gains. A national policy that seeks indiscriminate growth in the sheer volume of market transactions cammot be relied upon to recognize and respond to this point. Instead, policymakers must devise new economic tools for modeling the interrelationship between economic and ecological spheres of activity. Data derived from such tools can help inform the essentially moral decision of how best to regulate economic life to ensure sustainability for succeeding generations.

\section{Criticisms of Ecological Economics}

The work of ecological economists has attracted considerable criticism from mainstrean economists and other academics. As will be seen, these critiques frequently reflect misunderstandings about the basic premises of the new discipline. Moreover, they often raise points that are not in conflict with the writings of thinkers like Daly and instead play an even more central role in ecological economics than mainstream economics. Nevertheless, one particular critique-relating to the potential for market forces to cause resource conservation, technological innovation, and other limit-avoiding substitutions to arise as a matter of course from the market-represents a legitimate bone of contention with ecological economists. The debate cannot be resolved through theoretical analysis alone, but instead raises an em-

${ }^{207}$ Heinzerling, Discounting Life, supra note 190 , at 1915. 
pirical question that only will be answered by the unfolding of global events over time. In other words, the debate at present hinges not on economic logic, but on the faith one places in human knowledge and the view one holds of the ultimate goals of human activity.

\section{A. Sustainable Growth vs. Sustainable Development}

In a well-known article, philosopher Mark Sagoff challenged many of the teachings of ecological economics, including the view that growth in the economy is necessarily correlated with increased material throughput. ${ }^{208}$ As he notes, there is a great deal of evidence to suggest that increases in GNP may be achieved without corresponding increases in resource consumption or waste production. For instance, between 1973 and 1986 energy consumption in the United States remained virtually flat while economic production expanded by almost 40\%.209 Likewise, "[s] ince 1973, France and West Germany have decreased per capita emissions from fossil fuels as their economies have expanded." 210 In the United Kingdom, demand for primary energy sources was less in 1990 than in 1974, even though the country's national product had grown. ${ }^{211}$ Faced with evidence such as this, many commentators "[find] no reason to agree with the contention of ecological economists ... that growth in the sense of greater gross domestic product is unsustainable because it necessarily strains natural limits and leads automatically to resource depletion and ecological demise. ${ }^{212}$

Such criticisms unwittingly embrace the aspirations of ecological economists. Daly has steadfastly argued in favor of a conceptual distinction between types of economic expansion, a line which current national accounting measures such as GNP refuse to draw.. ${ }^{213}$ Specifically, Daly refers to an increase in the sheer physical scale of the human economy, including especially the volume of resource depletion and waste emission, as growth. ${ }^{214}$ The creation of value without a corresponding increase in the economy's physical burden on the

${ }_{208}$ Mark Sagoff, Carrying Capacity and Ecological Economics, 45 BroScIENCE 610, 614 (1995).

209 Michalit. Brower, Cool Energiv: Renewable: Solutions to Environmentat. Problems 13 (1992).

${ }^{210}$ See Sigoff, supra note 208, at 614.

211 See id.

212 Id. at (614-15.

${ }^{213}$ See DALY, supra note 58, at 28.

214 See id. 
environment, such as through increases in productive efficiency, Daly refers to as development. ${ }^{215}$

Making these distinctions explicit serves an important purpose for Daly: "We can ... distinguish growth (quantitative expansion) from development (qualitative improvement), and urge ourselves to develop as much as possible, while ceasing to grow, once the regenerative and absorptive capacities of the ecosystem are reached (sustainable development)."216 In other words, commentators who cite increases in productive efficiency as evidence of the possibility of economic expansion without environmental devastation have merely described the economy of sustainable development that Daly and other ecological economists advocate.

\section{B. The Solar Exception to the Laws of Thermodynamics}

Sagoff also has questioned the view that energy sources are subject to the laws of thermodynamics. ${ }^{217}$ By noting that "[i]f we ignore pollution problems, fossil fuels could subsidize the global economy for quite a while," 218 he purported to demonstrate that low-entropy terrestrial sources of fuel were not as limited as ecological economists portray. Of course, this argument appears to be challenging only the exact location of resource limits, not their existence. Moreover, in addition to the direct limit on fossil fuel production, there is also the indirect limit caused by the decreasing tolerance of the atmosphere to thermal waste. Exclusion of such "pollution problems" from consideration is a theoretical sleight of hand because pollution in the form of greenhouse emissions arguably has become the relevant constraint in fossil fuel consumption. "Indeed, falling [fossil fuel] extraction costs, considered as evidence against scarcity in another context, make the pollution problem worse [by increasing production]. ${ }^{219}$

In recognition of these constraints, Sagoff turns to renewable sources of energy, such as wind and solar power: "These sourceswhich dwarf fossil fuels in the amount of energy they make available-seem so abundant that for practical purposes they may be

215 See id.

216 See id. at 28-29.

217 See Sagofi, supra note 208, at 612-13.

218 Id. at 612.

${ }^{219}$ Herman E. Daly, Reply to Mark Sagoffs "Carrying Capacity and Ecological Economics, " 45 BioScience 621, 623 (1995). 
regarded as infinite." 220 Again, Sagoff does not appear to have challenged the laws of thermodynamics. He has only argued that, in light of the massive life expectancy of the sun, solar power may be considered so abundant that the laws of thermodynamics do not appear, to humans, to be binding. But binding they remain.

In essence, what Sagoff has done is accept Georgescu-Roegen's conclusion without accepting his logic. The very reason one should advocate conversion to renewable energy sources is that the laws of thermodynamics make their use' arguably utility-maximizing for human development. Widespread adoption of renewable energy sources greatly expands the expected length of human survival and therefore helps to increase population-wide utility over time. Such potentially welfare-enhancing choices are more likely to be made under an economic world-view which accepts the laws of physics. Sagoff's assumption-that "it is not obvious how the second law of thermodynamics limits economic growth"221_recognizes no adverse consequences from continued profligate consumption of fossil fuels, and therefore lends no urgency to the need to switch to "infinite" solar sources of energy. Georgescu-Roegen's assumption-that fixed amounts of "matter-energy enter[] the economic process in a state of low entropy and [necessarily] come[] out of it in a state of high entropy"222 -counsels the course of conduct that will result in the least reduction of lowentropy fuel sources in order to achieve a given level of output.

\section{Unemployment}

The primary means by which ecological economic proposals are attacked in popular discourse is through juxtaposition of environmental and economic ends as if the two cannot coexist. Of such attacks, the most familiar seems to be the contention that limiting exploitation of resources would slow the economy and raise unemployment. Such arguments can be very persuasive in a society where increasing numbers of people feel insecure in their present employment ${ }^{229}$ and where real income has been stagnant or declining for the last three decades. ${ }^{224}$

220 Sagoff, supra note 208, at 612.

$221 / d$. at 613.

222 Georgescu-Roegen, supra note 57, at 77.

223 Sep Vicki Schultz, Life's Work, 100 Colum. L. Rwv. 1881, 1924 (2000).

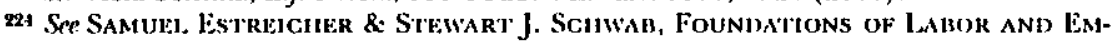
PLOYMENT LAW 36 (2000). 
Nevertheless, these arguments should be viewed with caution. The link between protecting the environment and raising unemployment is not unequivocal. Current fiscal policy taxes income, thereby raising the cost of labor, while not taxing, and frequently even subsidizing, energy production and resource extraction, thereby lowering the cost of capital. The natural result of such a state is to depress demand for workers while raising demand for machines. Thus, "[i]n Canada, the world's biggest timber exporter, the number of jobs per volume harvested has fallen by 20 percent in the last 20 years, despite a substantial rise in harvest levels." 225 Shifting to a fiscal policy in which depletion quotas or taxes equalize the playing field between inputs would slow the drive toward automation and reduced use of labor:

Indeed, many sustainable business practices are more laborintensive than their nonsustainable counterparts. Organic farming, for instance, requires more workers per hectare than conventional farming. ${ }^{226}$ Meanwhile, the evidence does not seem to suggest that declines in per hectare (as opposed to per worker) productivity from such sustainable practices are inevitable or even likely. In Indonesia, for instance, fifty-seven of sixty-six pesticides used on rice have been banned since 1986 in an effort to respond to the adaptation of the brown planthopper to previous chemical spraying. ${ }^{227}$ Pesticide subsidies, which had previously been as high as $80 \%$, were phased out and funding was switched to integrated pest management, a technique that seeks to use natural pest control methods as the primary means of crop defense. ${ }^{228}$ "Since then, more than 250,000 farmers have been trained in IPM techniques, insecticide use has plunged by 60 percent and the rice harvest has risen more than 15 percent. Farmers and the Indonesian treasury have saved ... more than $\$ 1$ billion." 229 These possibilities are not restricted to Indonesia: experts estimate that pesticide use in the United States could be reduced by $50 \%$ for only a negligible (less than 1\%) increase in food costs. ${ }^{230}$

225 Abratnovitz \& Mattoon, supra note 79 , at 76.

226 See Keith Jauntgatad, Farm Labor and Management, in Planning The Future: Devel oping an Agriculture that Sustains Land and) Comnunity 83, 86 (Elizabeth Am $R$. Bircl et al. eds., 1995).

227 Paul R. Eurtich \& Anne H. Einglicit, Betrayal of Science and Reason 165 (1996).

${ }^{228}$ See id. at 165.

$2 \times 9$ Id.

${ }^{230}$ Sce id. at 160. 
The belief that ecologically sustainable business practices necessarily cause increased unemploynent may simply result from a lack of imagination. Recreational use of U.S. National Forests generates nearly 2.6 million jobs and adds $\$ 97.8$ billion to the national econony. Meanwhile, logging contributes only seventy-six thousand jobs and $\$ 3.5$ billion. ${ }^{231}$ Yet job creation is the constant refrain of policymakers who call for increasing harvest levels and industry subsidies. ${ }^{232}$ Institution of sustainable economic policies may result in dynamic shifts in job concentrations, rather than an absolute loss of employment. Indeed, the employment challenge facing ecological economists might well turn out to be less difficult than the one facing their growth-oriented counterparts, which is, " $[\mathrm{H}]$ ow can full employment be maintained in an economy that becomes ever more capital- and energy-intensive in its technology while at the same time facing ever greater scarcity of the nonrenewable resources upon which its technology is based?"23s

\section{The Possibility of Substitutes}

In response to the challenge of ecological economists, mainstream economists often cite the possibility of substituting resources whenever particular scarcities threaten to constrain growth. Solow expresses this position well: "It is of the essence that production cannot take place without some use of natural resources. But $I$ shall also assume that it is always possible to substitute greater inputs of labor, reproducible capital [e.g., technology], and renewable resources for smaller direct inputs of the fixed resource." ${ }^{234}$ Moreover, economists often envision this substitution as arising automatically from market forces. As resource depletion results in dwindling stocks, prices rise and producers switch to one of the other available substitutes for natural resources. In short, economists believe that "increasing resource scarcity ... always generate $[\mathrm{s}]$ price signals which ... engender compensating economic and technological developments, such as

231 See Abraunovitz \& Mattonn, supro note 79, at 76.

232 See id. at 75.

233 Herman E. Daly, Postscript: Some Common Misunderstandings and Further Issues Concerning a Steady-Siate Economy, in Valuing THE EARTI: Economics, Ecology, ETuics 365, 375 (Herman E. Daly \& Kenneth N. Townsend eds., 1993).

24 Solow, supra note 205, al 164. 
resource substitution, recycling, exploration, and increased efficiency in resource utilization." 235

This Section reviews a number of ways in which ecological economists have responded to this line of argument.

\section{Externalities}

In order for the market to effectively recognize resource scarcities and signal the need for substitution, prices must reflect all of the environmental costs associated with the production and consumption of a good. ${ }^{236}$ For instance, without some form of carbon tax placed on timber harvesting, worldwide lumber production could continue at a steady pace for at least a few more decades, with the market never recognizing a resource scarcity and therefore never warning actors to substitute other inputs for lumber. At the same time, however, the consequent climate impact from deforestation-which accounts for as much as one-third of the carbon dioxide released into the atmosphere as a result of human activity ${ }^{237}$ - could impose costs on society of a tremendous magnitude. Ecological economists argue that externalities of this nature are a pervasive feature of market activity. Moreover, they argue that the modern understanding of ecosystem dynamics shows that externalities are far more complex and unpredictable than the simple polluting factory and neighboring clothesline posited as the standard economic example of such externalities. ${ }^{238}$

To enrich the textbook example, ecological economists describe actual and current cases in which market mechanisms cannot be relied upon to alert economic actors to scarcities of resources or impairments of ecosystem services. The most obvious examples occur in relation to what Daly calls the ecological "sink"-the land, water, and air systems that absorb the thermal waste of the economic process. ${ }^{239}$ As Hardin so eloquently pointed out, the waste absorption capacity of the enviromment is not subject to private ownership yet it is subject to

235 Colin W. Clark, Economic Biases Against Sustainable Development, in Ecolocical Economics: Tile Science and Management of Sustainability 319, 320 (Robert Cosiaiza ed., 1991).

236 See DA1Y, supra note 58 , at 54.

237 See Molly O'Meara, The Risks of Disrupting Climate, in WORLDWATch Reader on Glomal Environmental Issués 27, 54 (Lester R. Brown \& Ed Ayres eds., 1998).

298 See A. Mirchell Polinsky, An Introduction to Law and Economics 11-13 (1989).

${ }^{239}$ See Daly, supra note 140 , at 33. 
unrestrained private use. ${ }^{240}$ Thus, the arsonists who cleared land in Indonesia by burning two million hectares of forest during 1997 had no economic reason to consider the health costs to the more than twenty million people who breathed hazardous smoke-filled air, hundreds of whom were killed and thousands of whom were sent to medical treatment facilities. ${ }^{241}$ Similarly, a small but un-priced contribution to worldwide climate change is the direct and foreseeable consequence of every individual's turn of the ignition key in his or her car. Due to pervasive media coverage, this causal relationship is likely well-known, yet waste emissions continue to rise.

Other failures of the market to signal ecological scarcities result from "accidental" tragedies. Ecosystem processes are intensely complex and difficult to predict. Actions that are not motivated by the self-interest of the commons problem can still inadvertently result in ecological harm. For instance, farmers in industrialized nations have relied heavily on chemical pesticides and fertilizers to boost yields since the 1950s. Although the resulting "green revolution" fueled productivity growth for decades, ${ }^{242}$ unintended consequences of industrial farming have included an acceleration in the erosion of fertile topsoil, ${ }^{243}$ the rise of agricultural runoff to become a leading source of health-endangering water pollution in the United States, ${ }^{244}$ and the destruction of non-pest species such as pollinator insects that are indispensable to the production of other crops. ${ }^{245}$ These consequences are likely not the result of deliberate, self-interested externalization by agribusiness. However, their occurrence is just as much a tragedy of the commons as if they had been.

As an example of just how unexpected and dramatic the impact of economic activity can be on delicate ecosystems, consider the case of ballast water which is pumped in and out of ships as they follow international trading routes. "Ballast water exchange has become a

240 See Harclin, supra note 43 , at 1245.

241 See Abramovitz, supra note 136, at 150-51.

242 See Mona l. Hymel, The Population Crisis: The Stok, the Plow, and the IRS, 77 N.C. L. Rvv. 13, 78-79 (1998). There are clear signs, however; that the revolution has ended: "Global grain production per person has slipped downward since 1985." Id. at 79.

243 See id. at 80-81.

244 See id. at 82-83. Nitrogen from fertilizers can be toxic to humans, especially children. See id. at 84 . Likewise, "[t]he EPA considers at least $62 \%$ of all pesticides to be carcinogenic or potentially carcinogenic." Id. at 85.

245 See Abramovitz, supra note 136, at 161 . The severity of this situation slould not be underestimated: "One-iliard of U.S. agricultural oupu is from insect-pollinated plauts ...."Id. 
manmade overlay to the globe's natural currents-a network of artificial rivers running through the oceans."246 Among the myriad small creatures that follow these artificial currents is the comb jelly which has been discharged into the Black Sea by ballast water carried from far off ecosystems. ${ }^{247}$ The companies responsible for the transport of the comb jelly almost certainly did not include in their cost calculations the devastation of Black Sea fisheries that resulted from massive proliferation of jellies. ${ }^{248}$

Examples of costs that fall outside the purview of market mechanisms-both unintentionally and as a result of the common resource problem-abound. Still other examples result from the market's failure to recognize that natural capital can be depleted when harvested faster than its rate of regeneration. Drawing down natural stocks at a rate faster than they regrow imposes an externality on future generations-it reduces the resource base available to provide a stream of ecological goods and services in the future. For this reason, economist H. Scott Gordon's classic article discussing the difficulties inherent in any attempt to prevent short-sighted depletion of fishery stocks ${ }^{249}$ has become an issue of actual, rather than mere academic, concern. Seventy percent of the earth's major fish species are either fully or overexploited, while keystone species such as sharks, tuna, swordfish, and cod are at their lowest points in history. ${ }^{250}$ Similarly, while one-third of Asia's forest cover has been lost since 1960, the economic calculus behind such massive logging efforts probably did not consider the lost value to future generations of such forest services as the provision of habitat for diverse plant and animal species, the stabilization of soil cover to slow erosion and prevent landslides, the purification and protection of watersheds, and the absorption of atmospheric carbon. 251

For at least three reasons, therefore, resource scarcity in the traditional economic sense of the term may not be sufficiently correlated with environmental damage to ensure substitution as a panacea for ecological crises. First, the commons problem may cause selfinterested behavior that results in an overall reduction in social welfare. Second, the complexity of ecological interactions can lead to un-

246 See Chris Bright, Bio-lnvasions, in WORLdwatch Reader on Global EnvironMENTAL Issues 115, 123 (Lester R. Brown \& Ed Ayres eds., 1998).

247 See id.

248 See id.

249 See Gordon, supra note 44.

${ }^{250}$ See McGinn, supra note 13, at 83.

251 See Abramovitz, supra note 136 , at 157. 
intended or unrecognized, and therefore uncalculated, consequences from economic activity. Third, the failure to conceive of natural resources as capital goods requiring conservative management can externalize costs onto future generations by reducing the resource base that will be available to them. So long as these possibilities for externalizing costs exist, ecological economists believe there will be inadequate incentives to invest in developing technological improvements or resource substitutes.

Of course, even with a failure to internalize costs, substitutes may develop when a particular type of natural capital or ecosystem service becomes so scarce that its commodification becomes profitable. But there is no sense in which this type of substitution is optimal. The reduction in availability of such capital and services will have occurred in the absence of government policies that internalize the costs imposed on present and future generations, making it simply unknown whether the private decisions giving rise to the resource scarcity were welfaremaximizing. For instance, some may take solace in the fact that oxygen tanks have become a saleable commodity in heavily polluted cities. ${ }^{252}$ They may view this as a sign that the market is working and that even the seemingly unavoidable constraint of the atmosphere can be circunvented by substitution, at least on a local level. They would be wrong to assume, however; that this development has been welfaremaximizing, given that it resulted from a series of private decisions that did not take account of the full consequences of contemplated actions.

\section{Scale}

The preceding discussion underscores a second way in which ecological econonnists challenge the mainstrean economist's faith in the possibility of substitution. Traditionally, economists who recognize external effects from economic activity propose the imposition of a tax on the activity equal in amount to the externalized harm. They argue that if society levies a duty in this mamner, private economic decisions will be forced to take account of the full social cost of a contemplated activity. Resulting action will then represent a welfare-

252 See Harald Maass, Fresh Air in Beijing Comes in Tube; Uncontaminated Breathing Proves an Enticing Novelly, S.F. Examınke, July 2, 1995, at $A 13$ (clescrilsing how in Beijing, one of the world's ten worst cities for air pollution accorling to the World Health Organization, people have begun frequenting "oxygen bars" and purchasing "U.S.-manufactured matchines that emit oxygen"). 
maximizing choice in that it only will be undertaken if private benefits exceed the full costs of the action. However, ecological economists argue that this tendency to confront externalities through the use of microcontrols such as environmental taxes cannot be relied upon to resolve ultimate decisions regarding the scale of the macroeconony. Just as questions of intergenerational distributive equity cannot be subsumed within the discount rate, ${ }^{253}$ questions of scale cannot be incorporated into the price mechanism.

Returning to the example of the polluted cities that have resorted to selling oxygen, consider the difficulty of designing an optimal tax that would have ensured that private decisions resulted in a socially-desirable level of pollution. This exercise would have required, first, determining the precise atmospheric effect of all possible human influences on the pollution level and, second, assigning a price to each such influence in proportion to its effect. The price would have had to somehow quantify the value that the community places on the quality of its air, taking into account both identifiable costs such as health-related expenses and less tangible costs such as the disutility of labored breathing. Obviously, such an exercise is fraught with practical difficulty. Given the pervasiveness of environmentally-destructive external effects from market transactions, the difficulty of predicting or even recognizing such effects, and the near impossibility of placing reliable dollar figures on them, ecological economists believe that environmental taxes cannot attain the comprehensiveness and accuracy needed to ensure ecological stability by themselves. ${ }^{254}$

More importantly, even if optimal environmental taxes somehow could be devised, the resulting path of development would represent society's "chosen" path only in a very strained sense, given that it would have resulted from a multitude of atomistic individuals making atomistic decisions that purportedly included full consideration of the environmental, social, and psychological consequences to the community from the contemplated action. Requiring individual consumption choices to perform that much work in one's political economic theory seems fanciful. Regardless of what tax is placed on a gallon of gas, individuals cannot be expected to conceive of the decision to start their vehicle as a "vote" on whether society should pollute its atmosphere or deprive future generations of climatic stability. As eco-

253 See supra text accompanying notes 190-207.

254 See DALY, supra note 58, at 54. 
logical economists argue, directly addressing such issues of scale seems a much more efficient, and ultimately more reliable, means of collective governance. Or, as Daly put it, "When increasingly vital facts, including the very capacity of the earth to support life, have to be treated as 'externalities,' then it is past time to change the basic framework of our thinking so that we can treat these critical issues internally and centrally." ${ }^{255}$

\section{Technology}

Still, many economists and public policy specialists continue to contest the view that natural systems constrain the economy, believing instead that an infinite fund of human intellectual capital can always overcome problems of depletion and pollution. "The basic economic resource-'the means of production,' to use the economist's term-is no longer capital, nor natural resources .... It is and will be knowledge." 256 Essentially, these commentators argue that regardless of how severely human activity taxes natural resources, human ingenuity is the "ultimate resource." 257 After all, technological innovations have demonstrated an astounding ability to circumvent envirommentally imposed limits throughout modern history. Why should there be any reason to suppose that advances in human knowledge and technological achievement cannot continue to drive economic growth, regardless of nature's roadblocks? Solow once characterized this view as follows: "If it is very easy to substitute other factors for natural resources, then ... the world can, in effect, get along without natural resources, so exhaustion is just an event, not a catastrophe." ${ }^{258}$

On one level, of course, this view is at odds with reality. As has been explained by Georgescu-Roegen, absolute availability of natural resources is limited such that substitutability, however perfectly executed, cannot support limitless growth. ${ }^{259}$ Economists who appeal to substitutability seem to be arguing that although specific resources may become scarce or even extinct, there can be no general scarcity of resources. The laws of thermodynamics render this statement false.

255 Id. at 45 .

256 Pejer F. Drucker, Post-CaptTalist' Suciety 8 (1993).

257 See, e.g., Julian L. Simon, The Ul'tmate Resource (1981); Julian L. Simon, Rp. sourres, Population, Environment: An Ouersupply of False Bad News, 208 Scr. 1431 (1980).

258 Solow, stipra note 204, at 11.

259 See Georgescu-Roegen, supra note 67, at 92 ("One must have a very erroncous view of the economic process as a whole not to see hat there are no material factors other than natural resources."). 
The fixed stock of matter-energy in the universe flows inevitably toward a state of decreasing utility, in the economist's parlance.

Thermodynamic theory aside, however, it must be acknowledged that the technological optimist's argument carries force. As an initial matter, the astounding scientific achievements of the twentieth century offer ample historical evidence against the gloomy predictions of technological pessimists. Moreover; as. Sagoff's description of the availability of solar entropy suggests, humanity may have a viable end route around resource constraints, at least for as long as anyone at this point could conceivably care. ${ }^{260}$ That is, if the world were to switch entirely to renewable resources tomorrow, then there might be no general scarcity of entropic flow for some five billion years, assuming that no other ecological constraints become binding. In a practical sense, therefore, one might say that resources are not limited simply because of the second law of thermodynamics. ${ }^{261}$

All of this raises an important question: assuming that scientists and technological innovators can be relied upon to circumvent naturally imposed constraints on economic growth, why should any attention be paid to the scale of the economy at all? In other words, even if Daly is right that increasing scale is a neglected problem in economics, why should it matter if scientific and technological capabilities increase in conjunction with the economic scale?

One important answer to this question is that society may not actually prefer human-made substitutes to naturally provided goods and services, irrespective of whether such technological substitutes are feasible. The decision to require substitution therefore should be made transparently rather than through millions of seemingly umrelated market transactions. Put differently, it may be a scientific (and economic) achievement to continue supplying oxygen to humans through tanks when the atmosphere itself becomes poisonous. Whether that represents the first-best world is a separate question altogether. In that regard, the many paeans to conservationist, community-based, simplistic living that have captured popular imagination in

260 See supra text accompanying notes 217-222.

261 This would be trite only if the predicate conversion to renewable energy were satisfied. As noted above, widespread adoption of renewalble energy is a measure that appears to follow inevitably from the ecological economist's worldview but only begrutgingly (and perhaps too late) from the mainstream economist's. See supra text accompanying notes $217-222$. 
recent decades ${ }^{262}$ might reflect a widespread and ummet desire for precisely the type of control over scale that ecological economists advocate.

A second answer is that the economist's belief in technological advancements depends on a debatable view that man-made capital and natural capital are perfect substitutes. Daly argues that this conception is misguided: "Man-made capital and natural capital are fundamentally complements and only marginally substitutes." 263 One can conceive of situations in which man-made capital or increases in productive efficiency can substitute for a limited amount of a particular natural resource in a given field. For example, when petroleum resources needed to maintain asphalt roads become scarce, one can substitute increased investment in car repair. ${ }^{264}$ This marginal substitutability, however, does not alter the fact that roads and cars are fundamentally. complements, just as all human labor and man-made capital are complements to natural resources. As Daly describes, "[O]ne cannot build the same wooden house with half the timber no matter how many saws and carpenters one tries to substitute."265

This view seems correct. One can substitute for a scarce but necessary resource at the margin-for instance, by using oxygen tanks in a polluted city-but one cannot substitute for the resource in its entirety. The debate between mainstream and ecological economists would then appear to be over how large the margin of substitutability really is; in other words, over how much faith to place in the power of technology and human resourcefulness. Daly, the technological pessimist, views complementarity between input factors as the overwhelming norm, while optimistic mainstream economists view the marginal substitutability of man-made capital and natural resources as covering a very wide margin. As a matter of theoretical analysis, neither side of the debate holds a logically superior position. The remainder of this Section reviews a few pieces of empirical evidence that lend support to the ecological economists' view. Nevertheless, it must

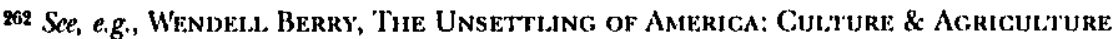
(1977); Duane Elgin, Voluntary Simplicity: Towaro a Way of life That Is OuTWardiy Simple, Inwarbly Rich (198I); Paul Hawken, The Ecology of Commerce: $A$ Declaration of Sustainabituty (1993); Fred Hirscit, Social Limits to Growih (1976); AMory B. Lovins, SOFJ Energy Patits: Toward a DURable: Pleace (1977); Jul.je:' B. Scior, Tim Overworked American (1991); E.F. Schumacher, Smal. is Biautiful. (1973).

263 DALY, supra note 58, at 76 .

2art See id. at 77.

gas Id. at 76. 
be acknowledged that the issue is a matter of present faith and only future verification.

As noted above, given the anticipated lifespan of the sun, entropic solar flow may not cease for billions of years. ${ }^{266}$ Many mainstream economists find support for their views in this possibility: "Nature need not limit economic growth ... as long as knowledge increases and the sun shines." 267 However, research by Peter Vitousek and colleagues on the concept of global "net primary production" suggests that even the "inexhaustible" resource of the sun imposes current limits on the scale of human economic activity (as opposed to temporal limits resulting from the sun's active lifespan). ${ }^{268}$

Net primary production refers to the amount of solar energy captured by all life forms on the earth, less the energy used in their own growth and reproduction. Unlike fossil fuels, which humans can consume at a rate largely of their own choosing, the flow of solar energy cannot be accelerated. The earth receives only a fixed annual supply of solar radiation. Of this fixed supply, Vitousek and his colleagues calculate that "approximately $40 \%$ of the present net primary production in terrestrial ecosystems is being co-opted by human beings each year:" 269 In other words, almost half of the solar energy that reaches land areas is currently being used to serve human needs. Inasmuch as economic growth depends on further human appropriation of potential terrestrial productivity, there would appear to be a definite limit to economic expansion: "If we take this percentage [of $40 \%$ ] as an index of the human carrying capacity of the earth and assume that a growing economy could come to appropriate $80 \%$ of photosynthetic production before destroying the functional integrity of the ecosphere, the earth will effectively go from half to completely full during the next ... 35 years. ${ }^{270}$

This limit might be better understood through a simple, wellknown thought experiment. Imagine a pond containing a weed that

206 See supra text accompanying note 261.

${ }^{207}$ Sagoff, supra note 208, at 614.

268 Peter Vitousek et al., Iuman Appropriation of the Products of Photosynthesis, 36 BioSCIENCE 368 (1986).

$269 \mathrm{Jd}$. at 372 . The figure is $25 \%$ for total global net primary prodiction, including photosymthesis which occurs in the ocean. The higher terrestrial percentage is considered the relative constraint, given humanity's primarily land-based existence.

270 W. E. Rees \& M. Wackernagel, Ecological Footprints and Approprinted Carrying Capacity: Measuring the Natural Capital Requirement of the Human Economy, in INvesting in NaturaL. Capital. 'Tite Ecological. Approach to Sustainability 362, 383 (A. Jansson et al. ells., 1994). 
doubles in surface coverage every day and will cover the entire pond in thirty days. ${ }^{271}$ On the twenty-ninth day, the pond will be just half full, a relatively mild state of affairs that hardly seems to portend that in just one day the pond will be completely smothered. If Vitousek's calculation of human appropriation of terrestrial photosynthetic product is correct, humans currently fill about half of the global pond.

Another useful thought experiment to demonstrate the complementarity of man-made and natural resources comes from Harrison Brown. ${ }^{272}$ Suppose that all of the physical capital stock of the world were annihilated overnight, but everything else (labor, knowledge, natural resources, and so on) remained unchanged. Could society conceivably replace the lost physical capital over any time span? Recent analysis of data on world oil resources suggests that roughly one trillion barrels of oil remain to be extracted. ${ }^{273}$ Because approximately eight hundred billion barrels have been consumed to date, ${ }^{274}$ a little over half of the original exploitable base of oil remains. Thus, taking oil as a resource benchmark, one might presume that existing manmade capital could be replaced by exploiting global oil and other natural resource reserves (barring pollution problems, of course). This presumption, however, fails to account for the fact that the existing physical infrastructure was constructed with the most easily available natural resources. "The reconstruction could not start again with East Texas oil, but would have to start with offshore Alaskan oil to be exploited without the further natural subsidy of Mesabi range iron ore." ${ }^{275}$ Under such conditions, the possibility of reconstructing modern society seems much less certain-availability of natural resources would pose a real and unavoidable limit on economic activity.

Finally, consider data offered by Lester Brown of the Worldwatch Institute regarding the capacity of global agricultural production to meet expected increases in population over the next half century. ${ }^{276}$ While technological advances in irrigation, crop breeding, and

271 See Paul R. Ehrlich \& Anne H. Ehrlich, Why Isn't Everyone as Scared as We Are?, in VAluing THE EARTH: Economics, Ecologr, Ertics 55, 57 (Iterman E. Daly \& Kentheth N. 'Townsend eds., 1993),

272 Harrison Brown, Human Materials Production as a Process in the Biosphere, Sct. AM., Sept. 1970 , at 195 .

273 Flavin \& Dumu, supra note 102, at 22, 24.

274 See id.

${ }^{275}$ DALY, supra nole 58, at 107.

276 See Lester R. Brown, Feeding Nine Billion, in STATt of Tute Wortb 115 (Lester R. Brown et al. c(ls., 1999). 
chemical use acted as marginal substitutes for the natural scarcity of cropland for several decades, since 1990 a different picture has emerged: "Between 1950 and 1990, the [agricultural] yield per hectare climbed by 2.1 percent a year, but during the 1990 s it has increased by only 1.1 percent a year." 277 Because increased amounts of fertilizers have little or no effect on yields past a certain point, fertilizer use has not increased in the United States since 1980.278 Modern wheat varieties, which are bred to convert more than $50 \%$ of the plant's photosynthetic product into seed, have little room left to increase yields before they reach the scientifically estimated absolute limit of $62 \%{ }^{279}$ Anything beyond that amount deprives the rest of the plant of energy needed to sustain leaves, stems, and roots. ${ }^{280}$

Growth in irrigated agriculture has also contributed to productivity gains in the past, but appears to have plateaued anidst increasing water scarcity. "Water tables are falling on every continent-in the southern Great Plains of the United States, the southwestern United States, much of North Africa and the Middle East, most of India, and almost everywhere in China that the land is flat." ${ }^{281}$ These areas of water depletion coincide with major agricultural areas for a reason: $70 \%$ of all water diverted worldwide is used for agricultural irrigation. ${ }^{282}$ Finally, there is the shrinking availability of cropland itself. Between 1950 and 1998, the grain harvested area per person dropped from 0.23 hectares to 0.12 hectares per person. ${ }^{289}$

Many see an uneasy future in these trends. The principal grain exporting countries of the world, which together account for $85 \%$ of worldwide exports, have stayed at or near two hundred million tons of available grain exports since $1980 .{ }^{284}$ This is after climbing from sixty million tons in $1950 .{ }^{285}$ The world currently contains around six billion people, an increase of 4.4 billion in the last century alone. ${ }^{286}$ If, as the United Nations expects, the total world population increases by

\footnotetext{
277 See id. at 128.

278 See id. at 127.

279 See id. at 120-27.

280 See id.

281 See Brown, supra note 276, all 124.

282 See id. at 125.

283 See id. at 121.

291 See id. at 131.

283 See id.

${ }^{286}$ See Lester R. Brown \& Cluristopher Flavin, A New Economy for a New Century, in SrA'tE OF THE WORLD 3, 8 (Lester R. Brown et al. eds., 1999).
} 
over three billion during the next half century, ${ }^{287}$ what man-made capital will substitute for global grain shortages? What technological innovation will boost yields when aquifers are depleted, topsoil eroded, and arable land paved over?

As argued above, the answers to these questions currently depend on faith, not economic logic. Thus, the decision whether to favor mainstream or ecological economic conceptions of the macroeconomy must depend on second-order principles about how to behave, individually and socially, in the face of uncertainty. The next subsection addresses the primary such principle advanced in favor of ecological economics.

\section{The Precautionary Principle}

Ecological economists believe that mounting evidence of environmental strain counsels conservativeness in the approach to questions of environmental import. The evidence suggests that ecosystem activity does not follow predictable paths of linear causation, nor does it necessarily sacrifice noncritical attributes first. ${ }^{288}$ For reasons such as this, ecological economists advocate use of the "precautionary principle," 289 a decision-theoretic principle that may be understood as a formal expression of the age-old adage, "Better safe than sorry." Supporters of the precautionary principle argue "that if it is known that an action may cause profound and irreversible environmental damage which permanently reduces the welfare of future generations, but the probability of such damage is not known, then it is inequitable to act as if the probability is known." 290 Instead, society should establish "safe minimum standards . . . for protecting Earth's life-support systems in the face of virtually inevitable unpleasant surprises." 291

As Daly has argued, precautionary policy measures might ironically serve to affirm the mainstream economist's belief in the power of technology:

287 Se United Nations, World Population P'rospects: The 2000 Revision (; (2001) (reporting projections of between 7.9 billion and 10.9 billion for world population in 2050 , will a medium variant of 9.3 billion).

288 See supra text accompanying notes 236-252.

280 See l'crrings, supra note 193 , at 153.

2907 . at $165-66$.

291 Paul R. Elurlich, Ecological Economics and the Camying Caparity of the Earth, in INves'ing; in Natural Camial: The Ecolocicat. Approncir to Sustainability 38, 49 (A. Jaisson et al. eds., 1994). 
If one is a technological optimist and believes that resources are unimportant for the economic process, then one should not object to a policy of limiting the resource throughput, thereby raising its price. Such a policy would induce exactly the technological advances that use resources more efficiently-the very technology in which the optimists have so much faith. If a side effect of reduced resource throughput is to gain some insurance under the precautionary principle, as well as to preserve more of the earth as habitat for other species, then why object? Does the ... technological optimist have the courage of his convictions? ... If technology is the answer, why not actively promote its advance? ${ }^{292}$

For these reasons-because the approach would yield significant current benefits and because the alternative may risk irreversible and catastrophic harm-ecological economists adopt the precautionary approach as a guiding principle in the face of uncertainty over the effects of human economic activity and the ability of human technology to correct for those effects. ${ }^{293}$

\section{Summary}

In a terse summary of the preceding debate, noted growth advocate Julian Simon complains, "Daly builds everything on a single premise, which is, resources are finite ...."294 Daly might properly respond, mainstream macroeconomists build everything on the opposite premise, which is, resources are infinite. Given that the latter premise is contrary to logic, experience, and the consensus of the global scientific community, ${ }^{295}$ it may not be radical to view ecological economists as standing on a more solid footing than mainstream economists. Ultimately, their differences come down to an empirical question that will be answered only with the passing of time. In the

292 Daly, supra note 219 , at 624 .

295 Allough a fuller treatment is beyond the scope of this Article, it must be acknowlerlged that the precationary principle is, in many respects under-tleorized and much in need of further analysis and reseach. 'The most obvious criticism of the principle, for instance, hightights the fact that the opportunity cost of "precaution" may in fact be more harmfiul than the cost sought to be avoided. See Frank B. Cross, Paradoxical Perils of the Precaltionary Principle, 53 Wash. \& LeE L. Rev. 851 (1996); see also John D. Graham \& JonaTHAN BAERT Wiener, Risk Versus Risk (1995).

${ }^{294}$ Jay Hauncock, Growth Can Be Bad, UM Economist Says, BaLT. Sun, Oct. 31, 1996, at 1C (quoting Julian Simon, professor of business at the University of Maryland).

295 See infra text accompanying note 322. 
face of such uncertainty, many legal scholars might prefer to side with the conservative approach adopted by ecological economists. Many also might side with ecological economists for the altogether separate reason that they favor greater control over the scale of the human economy, regardless of whether technological advances can or cannot avert environmental disaster.

\section{I. LAW AND ECOlOgical Economics}

Although few in number, there have been significant efforts to incorporate macroeconomic concepts into legal economic analysis. ${ }^{296}$ Moreover, certain specific subject areas have benefited greatly fiom scholarly application of macroeconomic insights, including international trade regulation, ${ }^{297}$ foreign and domestic monetary policy, ${ }^{298}$ as well as immigration, ${ }^{299}$ administrative, ${ }^{300}$ employment, ${ }^{301}$ taxation, ${ }^{302}$

296 See Jim Chen \& Daniel J. Gifford, Lau as Industrial Policy: Economic Analysis of Law in a New Key, 25 U. MrM. L. Rev. 1315, 1347-61 (1995); Driesen, supra note 18; Kelmau, supra note 19, at 1227-76; Lewin, supra note 18.

${ }_{297}$ See Robert M. Stern, Conflict and Cooperation in International Economic Policy and Laut, 17 U. PA.J. IN''1, Econ. L. 539 (1996).

298 See Tony Caporale \& Kevin B. Grier, A Political Model of Monetary Poticy with Application to the Rral Fed Funds Rate, 41 J.L. \& Econ. 409 (1998); W. Matk Crain \& Lisa K. Oakley, The Politics of Infrastructure, 38 J.L. \& ECon. 1 (1995); Danicl R. Fischel et al., The Regulation of Banks and Bank Holding Companies, 73 VA. L. Rev. 301 (1987); Ceoffrey P'. Miller, An Interest-Group Theory of Central Bank Independence, 27 J. Lecal. Srun, 433 (1998); Geofficy P. Miller, The Role of a Central Bank in a Bubble Economy. 18 Carnozo L. Rrs. 1053 (I996); Dominick Salvatore, The International Monetary System: Past, Present, and Future, 62 Ford 1, L. Rev. 1975 (1994); Kate Stith, Reniting the Fiscal Constinution: The Case of Gramm-RudmanHollings, 76 Cal. L. Rev. 595 (1988); Rajeshi Swaminallan, Regulating Development: Strustural Adjustment and the Case for National Enforcement of Economic and Social Rights, 37 Cotum. J. 'TrANSNA't't. L. 161 (1998).

299 See lloward F. Chang, Liberalized Immigration as Free Thude: Economic Welfare and the Optimal Immigration Policy, 145 U. PA. L. Rvv. 1147 (1997).

300 See Richard J. Pierce, Jr, Small Is Not Beautiful: The Case Against Special Regulatory Treatment of Small Firms, 50 ADMin. L. Rev. 537 (1998).

${ }^{301}$ See Joln J. Donolnte IIl \& Pcter Sicgelman, Law E' Macroeconomirs: Employment Discrimination Litigation Over the Business Cycle, 66 S. CAL. L. REv. 709 (1993); Daniel J. Gifford, Labor Policy in Late Tuentieth Century Capitalism: Nenu Paradoxes for the Democratic State, 26 Hofstra L. Rev. 85 (1997); Kelman, supra note 19; Gillian Lester, Careers and Contingeng, 5] Stan. L. Rev. 73 (1998); Gary Minda, Opportunistic Donusizing of Aging Workers: the 1990s Version of Age and Pension Discrimination in Employment, 48 HLAsTings L.J. 511 (1997); Andrew P. Morriss, Bad Data, Bad Economics, and Bad Poligy: Time to Five Wrongful Discharge Lau, 74 Tex. L. Rax. 1901 (1996); Daniel Shaviro, The Minimum Wage, the Earned Income Tax Credit, and Optimal Subsidy Policy, 64 U. Gun. L. Rev. 405 (1997); l'eter Sicgelman \& Jolnn J. Donubue III, The Selection of Employment Discrimination Disputes for Litigation: Using Business Cycle Effects to Test the Priest-Klein Hypothesis, 24 J. Lecal. Siud. 427 (1995). 
environmental, ${ }^{303}$ and criminal law. ${ }^{304}$ Despite these efforts, however, the law and economics movement remains primarily restricted to the application of microeconomic concepts to legal theory. This traditional exclusion of macroeconomic subject matter from law and economics raises an obvious question: Do we really need a macroeconomics for legal analysis?

The answer to this question requires a clear exposition of the subjects with which economics is concerned. As Daly has pointed out, there are three general dimensions to the economic problem: optimal allocation of inputs among uses, equitable distribution of wealth, and maintenance of economic scale within sustainable limits. ${ }^{305}$ The first dimension is the domain of microeconomics, while the latter two belong to macroeconomics. In both economic and legal economic analyses, attention has focused almost exclusively on the first of these dimensions. Traditionally, economists have argued that the best way to solve the distribution problem is to provide an effective answer to the allocation problem. ${ }^{306}$ By ensuring that resources are allocated to their most efficient uses, one maximizes the amount of wealth created, and hence, the amount of wealth available for distribution throughout society. ${ }^{307}$ Increases in economic productivity, therefore, can result, at least theoretically, in higher absolute levels of income for everyone and the possibility of significant upward mobility for some. In addition to providing an explicit laissez-faire response to the question of distribution, this growth-oriented policy also provides an implicit laissez-faire answer to the scale problem: by relying on economic growth as a response to the problem of inequitable distribu-

${ }^{302}$ See Lelward J. McCaffery, Tax Policy under a Hybrid Income-Consumption Tax, 70 Tex. L. Rev. 1145 (1992); Shaviro, supra note 301; Nancy C. Staudt, The Hidden Costs of the Progressivity Debale, 50 VAnd. L. Rev. 919 (1997).

${ }^{303}$ See Vandana Date, Global "Development" and Its Environmental Ramifications-The Interlinking of Ecologically Sustainable Development and Intellectual Pmperty Rights, 27 GoLden GATE U. L. REv. 631 (1997); Michael Wenig, Making Sense of Growth and Sustainable Development: Several Responses to Herman Daly's Latest Book, 28 ENv'T.. L. 235 (1998).

${ }^{304}$ See Phillip J. Cook \& Gary A. Zarkin, Crime and the Business Cycle, 14 J. Legat Srud. 115 (1985); Llad Phillips et al., Crime, Youth, and the Labor Markel, 80 J. Pot. Econ. 491 (1972).

${ }^{905}$ See DALY, supra note 58, at 50-51.

306 See id. at 51.

${ }^{307}$ See Sheldon Danziger \& Peter Gottschalk, Do Rising Tides Liff All Boats? The Impact of Secular and Cyclical Changes on Poverty, 76 M. Econ. Rev. Papers \& Proc. 405 (1986) (describing penpular argement that links poverty reduction to undifferentiated economic expattsion). 
tion, economists necessarily believe that the optimal scale of the economy is always "bigger."

Law and economics scholars have adopted a similar; albeit far more refined, position. Most law and economics thinkers accept Steven Shavell and Louis Kaplow's forceful argument that legal rules should be constructed to achieve optimal allocation of resources among competing uses, without concern for the distributional effects of such rules. As they argue, for every inefficient but desirably redistributive legal rule, one can imagine an alternate legal rule coupled with a redistributive tax scheme that would achieve the same desired wealth transfer without the efficiency loss. For that reason (along with its comparative administrative advantage at transferring wealth), the tax and transfer system should be the exclusive means for the government to address distributional concerns. ${ }^{308}$ Of course, because redistribution of income through the tax and transfer system is simply a matter of setting politically-determined levels of redistribution, its interest to legal economists has been somewhat negligible. Despite a recent provocative attempt to reconsider Shavell and Kaplow's argument on empirical and theoretical grounds, ${ }^{309}$ its hold over the discipline remains. Consequently, the question of equitable distribution, and with it the field of macroeconomics, has been largely removed from the domain of law and economics.

Thus, both economists and legal economists have found theoretical grounds for ignoring the problem of wealth distribution and the lesser-recognized problem of sustainable scale. Meanwhile, wealth disparities have risen to record levels, ${ }^{310}$ a fact that might reflect contemporary America's lack of political resolve to use the tax and transfer system in the manner hypothesized by Shavell and Kaplow. This

s08 See Louis Kaplow \& Steven Shavell, Fairness V'msus Welfare, 114 Hakv. L. Ruv. 961 (2001); Louis Kaplow \& Steven Shavell, Should Legal Rules Favor the Poor? Clarifying the Role of Legal Rules and the Income Tax in Redistributing Intome, 29 J. Lecst. Srud. 821 (2000); Louis Kaplow \& Steven Shavell, Why the Legal System is Less Lfficient than the Inrome Tax in Redistributing Income, 23 J. Lwoal Stun. 667 (1994) [hercinafier; Kaplow \& Shavell, Why the Legal System]; Steven Slavell, A Note on Efficiency rs. Distrilntional Equity in Legal Rulmaking: Should Distributional Equity Matter Given Optimal Income Taxation?, 71 AM. ECoN. Ass'N PAPERS \& Proc. 414 (1981).

${ }^{309}$ See Christine Jolls, Behavioral Economics Analysis of Redistributive Legal Rules, 51 VAN1). L. Rev. 1653 (1998).

${ }^{310}$ In 1996, the U.S. Bureau of the Census reported that there has been an escalating increase in income inequality since 1968: "T] the ratio of the average income of the top 20 percent of households to the bottom 20 percent went from 10.2 in 1968 to 12.5 in 1992 and 13.6 in 1994." Daniel H. Weinberg, A Brief Look at Postway U.S. Incone Inequality, U.S. Bureau of the Census, Cursent Population Reports, P60-191, at 2 (1996). 
failure cannot be considered a direct or intended consequence of Shavell and Kaplow's reasoning, of course. Their argument contemplates removing distributional issues from analysis of legal rules; it does not advise ignoring such issues in all aspects of political discussion.

Yet the effect of their analysis might be to do just that-economics, and in particular growth economics, has become the dominant language of political speech, to the point of largely drowning out other dialects. As one scholar put it, "the increasing domination of homo economicus is evidenced by the fact that public discourse has become hostage to economics and has begun to dance to, instead of call, the economic tune: it is thoroughly infiltrated by the economic mindset and attuned to its interests." $\$ 11$ Before such economics occupied the bulk of the political landscape, it may have been appropriate to ignore distributional concerns on the assumption that they would be dealt with by the moral and political will of the people. Now it has become arguably tantamount to assigning a zero value to the goal of equitable distribution. In other words, when economists and legal economists exclude certain issues from their discussion on the assumption that some other discipline or some other mechanism will address the excluded concern, they may in effect be relegating that concern to the dustbin of politics.

In the terms of Shavell and Kaplow's argument, while it may be true that "any regime with an inefficient [but redistributive] legal rule [can be replaced with an] efficient legal rule and a modified income tax system in which all individuals are better off," 112 the modified income tax system necessary to ensure that such a Pareto improvement actually eventuates may not be possible within a given political climate, including perhaps the current one. As a practical matter, therefore, Shavell and Kaplow's argument may demonstrate only that potential Pareto improvements may be gained by excluding distributive effects from the selection of legal rules. Whether legal decisionmakers should continue to ignore distributional effects when it is confidently known that the necessary "modified income tax system" will not be adopted-that is, when it is known that the redistribution necessary to achieve the Pareto improvement will not occur-is a question not di-

311 Allan C. Hutchinson, Life After Shopping: From Consumers to Citizens, in Consumer Law in tie Global. Economy 25 (lain Ramsay ed., 1997).

312 Kaplow \&: Shavell, Why the Legal System, supra note 308, at 669. 
rectly addressed by Shavell and Kaplow's argument, as they themselves acknowledge. ${ }^{313}$

Precisely the same analysis applies to the goal of sustainable scale. Although it has not appeared within the legal cconomic literature, one could make an argunent against the consideration of scale effects of legal rules that tracks Shavell and Kaplow's reasoning. The same response, however, would apply: whether ignorance of scale effects is justified in the face of legislative recalcitrance is a separate, and more difficult, question. Indeed, with respect to scale, the problem is worse because no mechanism analogous to the tax and transfer system exists to regulate the scale of the economy, even if economic discourse does not crowd the issue out of political attention. The problem of achieving a sustainable scale of the human economy is left as a macroeconomic goal better addressed through unique, macroeconomic policy instruments-yet no such instruments are in place. And to compound the problem, the current accepted wisclom regarding the distribution problem-that growth in the scale of the econony will raise absolute wealth levels for all market participants-directly conflicts with the goal of maintaining society's ecological footprint within sustainable parameters.

In short, current economic wisdom attempts to "solve" two of society's most urgent problems by trading them off against each other, and current legal economic wisdom appears to have found reasons for ignoring both. The inconsistency is not recognized because mainstream macroeconomics does not acknowledge the problem of regulating scale. Perpetual growth is considered a viable response to the distribution problem because no adverse consequences to such growth are recognized. In effect, economists believe that they have found the global free lunch. Critics of this economic policy are at a decided disadvantage in popular and scholarly debates because they cannot point to any harmful effects of growth. Instead, they can only argue that economic growth has not achieved the goal of reducing wealth inequality. But that failure is not enough to overcome the compelling force of Pareto improvement: if a few people are better off because of economic growth, and no one is worse off, how can growth be opposed?

313 See id. at 675 (" $\mathrm{An}$ argument sometimes offered in favor of redistribution through legal rules is that the tax system falls short of optimal redisuibutive taxation-perhaps because of the balance of political power in the legislature. This atguncmt raiscs questions that we do not seek to address about the finction of courts in a democracy:"). 
Ecological economists reveal the fallacy of this position by making the problem of sustainable scale an issue of explicit concern. Through the lens of ecological economics, growth economics becomes assailable not only because wealth increases might not "trickle down" in the predicted fashion, but also because the biophysical demands entailed by economic growth may have pushed the human economy toward unsustainable levels. Once one accepts the foundational principle of ecological economics-that the level of material throughput in the economy is subject to ecological constraints-the macroeconomic concerns of distribution and scale can no longer be pushed to the side in the ever-intensifying pursuit of allocative efficiency. Indeed, as noted above, there is some reason to believe that economic growth in America in the latter decades of the twentieth century has become harmful to society on net, once one considers the environmental and social externalities that are not ordinarily accounted for by macroeconomic indicators. ${ }^{314}$ Under such conditions, scale and distribution can no longer remain the neglected stepsiblings of allocation within the fanily of economic aspirations.

For at least two reasons, then, law and economics may be incomplete without some form of macroeconomics to inform its analysis. First, because no political mechanism analogous to the tax and transfer system exists to regulate the scale of the macroeconomy, legal economic scholars cannot safely ignore the scale effects of alternative legal rules in the way that they have ignored distributive effects. Second, because the traditional response of economists to the distribution problem is in direct conflict with the goal of sustainable scale, law and economics' continued ignorance of both problems may result in the discipline's long-term marginalization. In other words, if natural limits turn out to constrain the scale of the human economy in the manner hypothesized by ecological economists, then the economist's practice of postponing the problem of distribution by punting on the problem of scale will not be viable in the long run. In light of this possibility, legal economic scholars may be wise to address both problems now by allowing ecological economic insights to inform their analysis.

This methodological approach would have two obvious but important effects. First, it would force legal scholars to confront the problem of maintaining a sustainable economy in their relevant analyses. By incorporating ecological economic insights into legal policy discussion, legal scholars could essentially leapfrog mainstream

314 See supra text accompanying notes 143-172. 
economic thought to provide both the theoretical impetus for and the practical construction of policy tools that ensure long-term sustainability. The practical benefit of confronting the problem of scale is potentially enormous. Recently, 1586 scientists from 63 countries, including 104 of the 178 living Nobel Prize wimners in the sciences, signed the World Scientists' Call for Action at the Kyoto Climate Summit which stated that "the scientific community ha[s] reached a consensus that grave threats imperil the future of humanity and the global environment." 315 "The United States' failure to heed this call to action from many of the world's most learned scientific experts demonstrates the stranglehold that mainstream economic ideology has on the political mindscape. ${ }^{316}$ By incorporating ecological economic insights into their policy analysis, however, legal economic scholars could take an important step toward harmonizing economic and scientific concerns.

A secondary effect of such an effort likely would be to revitalize the debate over distributional equity. If it is accepted that sustainability requires limits to the physical strain placed by humans on the ecosphere, absolute growth in the scale of the human econony would no longer be available as an answer to the problem of inequitable distribution. Instead, society would have to address the problem directly as a necessary subissue to the problem of determining a permissible level of resource throughput that does not jeopardize the viability of future generations. Of course, Shavell and Kaplow's argument that distributional concerns are more efficiently addressed through the tax and transfer system than through legal rulemaking ${ }^{317}$ would still apply under such a worldview. However, legal scholars and legal decisionmakers would have renewed interest in making certain that the goal of equitable distribution is actually being served, or at least examined, by other political mechanisms. The difficult question of political philosophy not addressed by Shavell and Kaplow's argument ${ }^{318}$ might then become an issue of some urgency.

Either the primary or the secondary effect seems sufficient to justify the use of ecological economics in legal analysis, at least in the tentative manner practiced by this Article. If further justification is needed, one may consider the reputational benefits that would accrue

95 Union of Cotcerned Scientists, World Scientists' Call for Action, available at ht1p:// www.ucsusa.org/about/callforaction.html (last visited October 25, 2001).

316 See supra note 14.

317 See supra text accompanying note 308 .

318 Sce supra note 313. 
to law and economics from beating its parent discipline to a cosmological perspective that is arguably both inevitable and potentially preservative of the human species, if only it is achieved with requisite haste.

\section{Conclusion}

At the time Adam Smith developed the image of rational market behavior, science in general was captivated by Enlightenment notions of limitless human intellectual ability. ${ }^{319}$ That microeconomists have clung to these notions longer than practitioners of any other discipline reflects what Alfred North Whitehead called the fallacy of misplaced concreteness-a failure to recognize that one's abstract theories continually must be informed by the reality from which they were abstracted. ${ }^{320}$ Indeed, it has only been in recent years that scholars of behavioral law and economics have made progress in upsetting the presumption of rationality in legal economic analysis by incorporating the decidedly nonrational findings of cognitive psychologists. ${ }^{321}$

A similar historical analysis applies to macroeconomics. When the core concepts of macroeconomics developed, the world contained four billion less people than it does today. The preanalytic vision which informed the development of neoclassical thought was that of a world in which human activity was but a tiny fraction of global activity. Human use of resources and production of wastes was considered costless because the regenerative and absorptive capacities of the earth appeared to have no limits. Today, evidence to the contrary arrives with regularity, to the point that the Royal Society of London and the United States National Academy of Sciences issued an unprecedented joint action statement, warning: "The future of our planet is in the balance. Sustainable development can be achieved, but only if irreversible degradation of the environment can be halted in time. The next 30 years

s19 See Lester 'Tiurow, Dangeruus Currents 216 (1983) ("One of the peculiarities of economics is that it still rests on a behavional assumption-rational tulity maximization-that has long since been rejected by sociologists and psychologists who specialize in studying luman beltavion: Rational incliviclual ntility (income) maximization was the common assumption of all social science in the nistetents century, but only economics continues to use it.").

520 Whiteheal defined the fallacy as "neglecting the degree of abstraction involved when an actual entity is considered merely so far as it exemplifies certain categories of thouglit." Alfred NorTh W'htTelead, Process and Reality, An Essay in Cosmology 8 (David Ray Griffin \& Donald W. Sherburuc eds., 1978).

s21 See supra text accompanying notes $15-17$. 
may be crucial." 322 The continued dominance within economics of a view of nature as limitless demonstrates that macroeconomic theorists also may have committed Whitehead's anti-rationalist fallacy: "an arbitrary halt at a particular set of abstractions. "323

Yet surprisingly little recognition has been given to the fact that macroeconomics rests on what is arguably now a discredited woildview. Among economists, increasing divergence between theory and reality is accounted for by increasing recognition of "externalities," much like the Ptolemaic astronomers who attempted to save their model of circular planetary motion through desperate addition of epicycles. ${ }^{324}$ However, lest society is to risk growing beyond the biophysical limits of the earth (not to mention the point at which marginal costs of macroeconomic growth exceed marginal benefits), it seems appropriate to develop an alternative economics, one grounded in scientifically plausible visions of the relationship between economic and ecological spheres. What seems needed is a body of market principles built on the assumptions that natural resources are limited, that ecosystem services have value, and that the size of the human economy is a legitimate subject for social control. Because ecological economists have provided just that, their teachings may be of great use to legal scholars in the years to come.

322 Royal Society of London \& Unitho Sintres National Acapemy of Sciunces, Population Grow'ti, Resource Consumption, and a Sustainahle World (1992).

523 Wu'Tghliad, sttpra note 1 , at 289.

324 See Dal. \&c CoisB, supra note 132, at 53. 